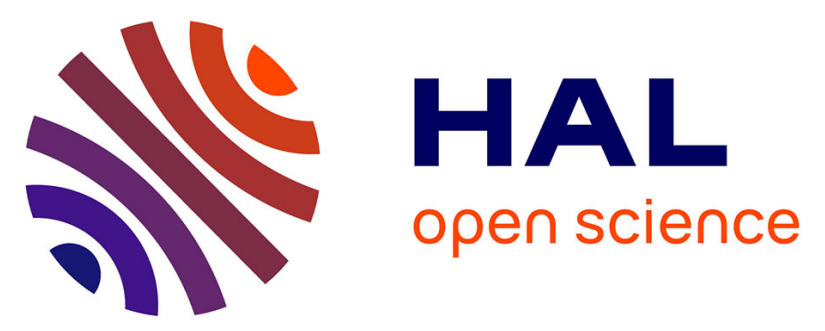

\title{
Reactive oxygen species enhance mitochondrial function, insulin sensitivity and glucose uptake in skeletal muscle of senescence accelerated prone mice SAMP8
}

Valentin Barquissau, Frédéric Capel, Dominique Dardevet, Christine Feillet Coudray, Anne Gallinier, Marie-Agnès Chauvin, Jennifer Rieusset, Béatrice Morio

\section{To cite this version:}

Valentin Barquissau, Frédéric Capel, Dominique Dardevet, Christine Feillet Coudray, Anne Gallinier, et al.. Reactive oxygen species enhance mitochondrial function, insulin sensitivity and glucose uptake in skeletal muscle of senescence accelerated prone mice SAMP8. Free Radical Biology and Medicine, 2017, 113, pp.267-279. 10.1016/j.freeradbiomed.2017.10.012 . hal-01658864

\section{HAL Id: hal-01658864 https://hal.science/hal-01658864}

Submitted on 26 May 2020

HAL is a multi-disciplinary open access archive for the deposit and dissemination of scientific research documents, whether they are published or not. The documents may come from teaching and research institutions in France or abroad, or from public or private research centers.
L'archive ouverte pluridisciplinaire HAL, est destinée au dépôt et à la diffusion de documents scientifiques de niveau recherche, publiés ou non, émanant des établissements d'enseignement et de recherche français ou étrangers, des laboratoires publics ou privés. 


\section{Author's Accepted Manuscript}

Reactive oxygen species enhance mitochondrial function, insulin sensitivity and glucose uptake in skeletal muscle of senescence accelerated prone mice SAMP8

Valentin Barquissau, Frédéric Capel, Dominique Dardevet, Christine Feillet-Coudray, Anne Gallinier, Marie-Agnès Chauvin, Jennifer Rieusset,

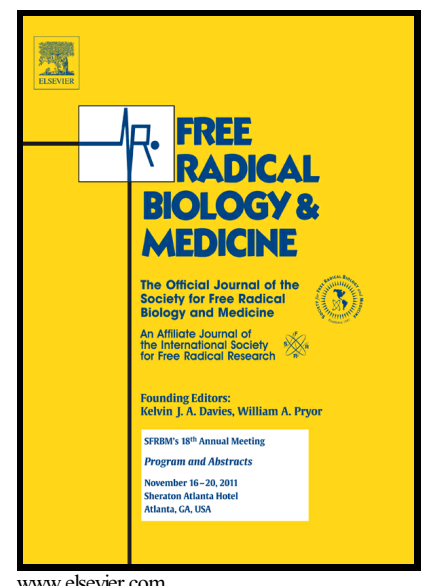
Béatrice Morio

PII: $\quad$ S0891-5849(17)30795-5

DOI: $\quad$ https://doi.org/10.1016/j. freeradbiomed.2017.10.012

Reference: FRB13480

To appear in: Free Radical Biology and Medicine

Received date: 16 March 2017

Revised date: 12 September 2017

Accepted date: 7 October 2017

Cite this article as: Valentin Barquissau, Frédéric Capel, Dominique Dardevet, Christine Feillet-Coudray, Anne Gallinier, Marie-Agnès Chauvin, Jennifer Rieusset and Béatrice Morio, Reactive oxygen species enhance mitochondrial function, insulin sensitivity and glucose uptake in skeletal muscle of senescence accelerated prone mice SAMP8, Free Radical Biology and Medicine, https://doi.org/10.1016/j.freeradbiomed.2017.10.012

This is a PDF file of an unedited manuscript that has been accepted for publication. As a service to our customers we are providing this early version of the manuscript. The manuscript will undergo copyediting, typesetting, and review of the resulting galley proof before it is published in its final citable form. Please note that during the production process errors may be discovered which could affect the content, and all legal disclaimers that apply to the journal pertain. 
Reactive oxygen species enhance mitochondrial function, insulin sensitivity and glucose uptake in skeletal muscle of senescence accelerated prone mice SAMP8

Valentin Barquissau ${ }^{1}$, Frédéric Capel $^{1}$, Dominique Dardevet ${ }^{1}$, Christine Feillet-Coudray ${ }^{2}$, Anne Gallinier ${ }^{3}$, Marie-Agnès Chauvin ${ }^{4}$, Jennifer Rieusset ${ }^{4}$, and Béatrice Morio ${ }^{1,4}$

${ }^{1}$ INRA UMR1019 Nutrition Humaine, Laboratoire de Nutrition Humaine, Université d'Auvergne, CRNH, 58 rue Montalembert BP321, 63009 Clermont Ferrand CEDEX 1, France.

${ }^{2}$ INRA UMR 866, Université de Montpellier, Montpellier, F-34060 France.

${ }^{3}$ 4STROMALab, Université de Toulouse, CNRS ERL5311, EFS, INP-ENVT, Inserm U1031, UPS, Toulouse, France

${ }^{4}$ INRA UMR1397, Laboratoire CarMeN, Inserm UMR1060, Université Lyon 1, INSA de Lyon, Faculté de Médecine Lyon Sud, BP 12, 165 Chemin du Grand Revoyet, 69921 Oullins Cedex, France

Correspondence:

Béatrice Morio, Laboratoire CarMeN, Faculté de Médecine Lyon Sud, BP 12, 165 Chemin du Grand Revoyet, 69921 Oullins Cedex, France. E-mail: beatrice.morio@inra.fr.

Short title: muscle metabolic adaptations to oxidative stress in SAMP8 
A.U., arbitrary unit; ADP, adenosine 5'-diphosphate; Akt, protein kinase B; ATP, adenosine triphosphate; CoQ9 and coQ10; coenzyme Q9 and Q10; COX, cytochrome c oxidase; COXIV, cytochrome c oxidase subunit IV; CREB, cAMP response element-binding protein; CS, citrate synthase; EDL, extensor digitorum longus; G/M, Glutamate and Malate; G/M/S, Glutamate, Malate and Succinate; GLUT4, Glucose transporter type 4; Gpx1, glutathione peroxidase 1; GSH, total glutathione; HPRT, hypoxanthine-guanine phosphoribosyl-transferase; IKK, nuclear factor-kappa B; JNK, c-Jun N-terminal kinase ; MAPKAP-1, mitogenactivated protein kinase associated protein 1; mtTFA, mitochondrial transcription factor A; NAC, Nacetylcysteine; ND, not determined; ND1 and ND6, NADH-ubiquinone oxidoreductase chain 1 and 6; NDUFB6 and NDUFB8, NADH dehydrogenase [ubiquinone] 1 beta subcomplex subunit 6 and 8; NFKB, nuclear factor kappa-light-chain-enhancer of activated B cells; NRF1 and NRF2, nuclear respiratory factor 1 and 2; NS, not significant; PGC-1alpha and beta, peroxisome proliferator-activated-receptor gamma coactivator 1alpha and beta; PP2A, protein phosphatase 2; PPARalpha and beta, peroxisome proliferatoractivated receptor alpha and beta; PTEN, phosphatase and tensin homolog; PTP1B, protein-tyrosine phosphatase 1B; RCR, respiratory control ratio; ROS, reactive oxygen species; SAMP8, senescence accelerated mice prone 8; SAMR1, senescence accelerated mice resistant 1; SOD, superoxide dismutase; $\mathrm{VCO}_{2}$, carbon dioxide production; $\mathrm{VO}_{2}$, oxygen consumption. 


\section{Abstract}

Whereas reactive oxygen species (ROS) can have opposite impacts on insulin signaling, they have mainly been associated with mitochondrial dysfunction in skeletal muscle. We analyzed the relationship between these three features in skeletal muscle of senescence accelerated mice (SAM) prone (P8), which are characterized by enhanced oxidative stress compared to SAM resistant (R1). Oxidative stress, ROS production, antioxidant system, mitochondrial content and functioning, as well as in vitro and in vivo insulin signaling were investigated in gastrocnemius and quadriceps muscles. In SAMP8 compared to SAMR1, muscle content in carbonylated proteins was two-fold $(\mathrm{p}<0.01)$ and ROS production by xanthine oxidase $70 \%(\mathrm{p}<0.05)$ higher. Furthermore, insulin-induced Akt phosphorylation measured in vivo and ex vivo as well as muscle glucose uptake measured ex vivo were significantly higher $(\mathrm{p}<0.05)$. Mitochondrial respiration evidenced uncoupling and higher respiration rates with substrates of complexes II and IV, in agreement with higher maximal activity of complexes II and IV (+18 and 62\%, respectively, p<0.05). By contrast, maximal activity of complex I was $22 \%$ lower $(\mathrm{p}<0.05)$. All strain differences were corrected after 6 months of N-acetylcysteine (NAC) treatment, thus supporting the involvement of high ROS production in these differences. In conclusion in muscle of SAMP8 compared to SAMR1, high ROS production is associated to higher insulin sensitivity and glucose uptake but to lower mitochondrial complex I activity. These conflicting adaptations, with regards to the resulting imbalance between NADH production and use, were associated with intrinsic adjustments in the mitochondrial respiration chain (mitochondrial uncoupling, enhanced complexes II and IV activity). We propose that these bioenergetics adaptations may help at preserving muscle metabolic flexibility of SAMP8. 


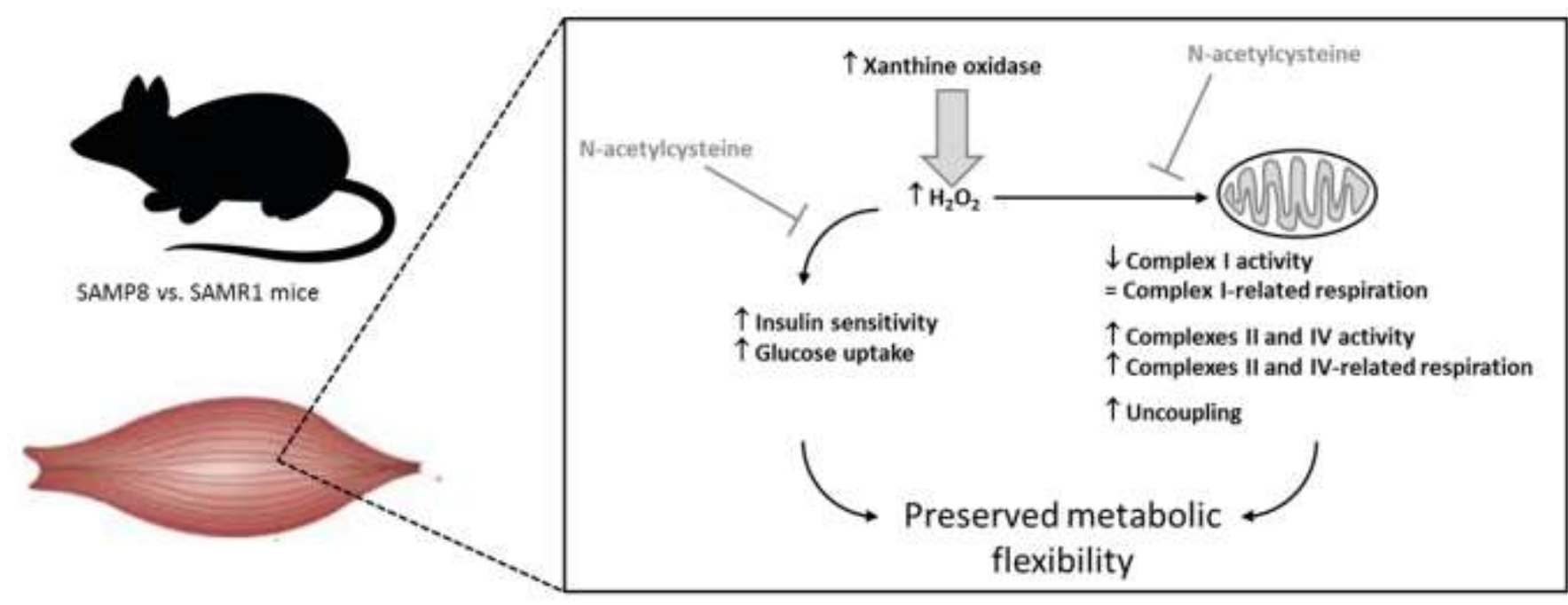

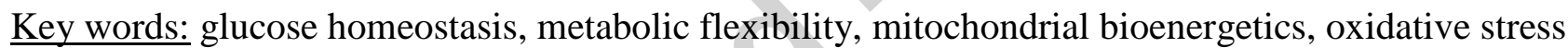




\section{Introduction}

Skeletal muscle is the main tissue involved in insulin-stimulated glucose disposal, so that insulin resistance

in obese and type 2 diabetic patients is mostly accounted for by a default in muscle glucose uptake $(1,2)$.

Oxidative stress is increased in skeletal muscle in situation of insulin resistance and type 2 diabetes (3), partly because of enhanced xanthine oxidase activity (4). Chronic exposition to high level of hydrogen peroxide $\left(\mathrm{H}_{2} \mathrm{O}_{2}\right)$ has been implicated in the etiology of insulin resistance, especially through alterations in protein structure and phosphorylation state, cellular localization and half-life, and gene expression (5). In addition, $\mathrm{H}_{2} \mathrm{O}_{2}$ activates signaling pathways involving JNK (c-Jun N-terminal kinase), IKK (nuclear factorkappa B) and NFאB (nuclear factor kappa-light-chain-enhancer of activated B cells) that interfere with the insulin signal transduction pathway (6-9). In those pathological contexts, antioxidant treatments improve or restore insulin sensitivity in various models from cell cultures to humans (10-12). Contrasting with these observations, $\mathrm{H}_{2} \mathrm{O}_{2}$, even at high (millimolar) concentrations, has been shown to have insulin-mimicking effects in healthy situations, mainly by inhibiting phosphatases such as PTP1B (protein-tyrosine phosphatase 1B), PTEN (phosphatase and tensin homolog), PP2A (protein phosphatase 2) and MAPKAP-1 (mitogenactivated protein kinase associated protein 1)(13). Hence in explant of extensor digitorum longus (EDL) muscle from rodents, 0.6 and $3 \mathrm{mM}$ of $\mathrm{H}_{2} \mathrm{O}_{2}$ acutely stimulated the phosphorylation of AktSer ${ }^{473}$ (7 and 8fold, respectively) as well as glucose uptake (3 and 1.4-fold, respectively) (14,15). In vivo, Loh et al. (16) reported that mice lacking glutathione peroxidase 1 (Gpx1) were protected from high-fat-diet-induced insulin resistance. The increased insulin sensitivity in those Gpx1(-/-) mice was attributed to insulin-induced phosphatidylinositol-3-kinase/Akt signaling and glucose uptake in muscle and was reversed by the antioxidant $\mathrm{N}$-acetylcysteine (NAC).

Oxidative stress has been shown to induce severe alterations in mitochondrial structures and functions, and these damages are reversed by antioxidant treatment $(3,17)$. Hence, oxidative stress has been identified as a major cause of mitochondrial damages in skeletal muscle of insulin resistant animals (3). However, these observations have been performed in diseased models when type 2 diabetes is established. It is thus still unknown whether mitochondrial functions are altered in situations when oxidative stress is associated with improved insulin signaling. Exploring this association would provide news arguments to better understand 
whether a direct relationship exists between insulin signaling and mitochondrial function, a question that has been challenged a lot for the last decades (18).

The present study aimed therefore at exploring the relationship between enhanced oxidative stress, due to increased $\mathrm{H}_{2} \mathrm{O}_{2}$ production, insulin signaling and mitochondrial function in the skeletal muscle of a mouse model of accelerated senescence, the senescence-accelerated mice prone 8 (SAMP8). Data were compared to observations made in a control model, the senescence-accelerated mice resistant 1 (SAMR1). SAMP8 mice have been previously shown to spontaneously develop oxidative stress, especially in skeletal muscles (19). However whereas oxidative stress is a consistent observation in the skeletal muscle of SAMP8 mice, discrepant results have been obtained on the insulin response (20-22) and few studies have explored the mitochondrial functions (23-24).

\section{Materials and Methods}

\section{Chemicals}

Primary antibodies for Ser473-pAkt and total Akt were from Cell signaling (Danvers, USA), those for xanthine oxidase and GLUT4 were from Santa Cruz Biotechnology (Dallas, USA). Other chemicals (e.g. Nacetylcysteine, cytochrome c, DNP) were from Sigma-Aldrich (Saint-Quentin Fallavier, France).

\section{$\underline{\text { Treatments of animals and muscle collection }}$}

Female SAMP8 (INRA Dijon, France, $n=80)$ or SAMR1 $(n=80)$ were housed in groups of four on sawdust bedding in plastic cages from age 6 to age 12 month old. Artificial lighting was provided on a fixed $12 \mathrm{~h}$ light-dark cycle with standard food and water ad libitum. Forty SAMP8 and SAMR1 received during this 6month period around $15 \mathrm{mg} /$ day NAC in drinking water $(2 \mathrm{~g} / \mathrm{l})$. This study was approved by local ethic committee and record for number CE10-06 (modified) and was conducted in accordance with the Guidelines for Animal Research by the International Association for the Study of Pain (25).

\section{Indirect calorimetry:}

Oxygen consumption $\left(\mathrm{VO}_{2}\right)$ and carbon dioxide production $\left(\mathrm{VCO}_{2}\right)$ were measured using a four-chamber TSE systems PhenoMaster/LabMaster (Bad Homburg, Germany) over 24 hours, after a 16h adjustment period. Mice had free access to food and water. Temperature was maintained at $28^{\circ} \mathrm{C}$ to reach the animal 
thermoneutrality and the light was on from 8:00 a.m. to 8:00 p.m. System settings included a flow-rate of $0.6 \mathrm{l} / \mathrm{min}$, a sample purge of $5 \mathrm{~min}$ and a measurement period of $5 \mathrm{~min}$ every $25 \mathrm{~min}$. Daily energy expenditure (26) and respiratory quotient (RQ; ratio of $\mathrm{VCO}_{2}$ to $\mathrm{VO}_{2}$ ) were computed over the $24 \mathrm{~h}$ measurement period.

\section{Plasma analyses}

Blood samples were collected in EDTA-tubes and centrifuged at $3000 \mathrm{~g}$ to separate plasma. Plasma concentration of glucose, non-esterified fatty acids, glycerol and triglycerides was measured using the automated analyser (Konelab 20, Thermo Electron, Waltham, USA) and biochemical assay kits purchased from Thermo Electron Corporation (Waltham, USA). Insulin was assayed using commercial enzyme-linked immunosorbent assay (ALPCO diagnostics, Salem, USA).

\section{$\underline{\text { Analyses on muscle homogenates }}$}

After an overnight fast, animals ( $\mathrm{n}=10$ per group) were anaesthetized by an intraperitoneal injection of pentobarbital and euthanized by full blood redrawing from the abdominal aorta. Gastrocnemius were quickly removed, separated from fat and connective tissues and processed for further analyses.

Protein carbonylation: The Oxyblot Oxidized Protein Detection Kit was purchased from Chemicon.

The carbonyl groups in the protein side chains were derivatized to DNP-hydrazone by reaction with DNPH following the manufacturer's instructions. Thereafter, a standard western blot procedure was conducted as described below to quantify DNP radicals.

Maximal activity of antioxidant enzymes: The tissue was rinsed in Krebs buffer, and homogenized using an Ultra Turrax T25 basic (Irka-Werke) in ice-cold Krebs buffer. Measurements of maximal activity of glutathione peroxidase (GPX), catalase and total and manganese superoxide dismutases (SOD and MnSOD), were performed according to the methods of Flohe and Gunzler (27), Beers and Sizer (28) and Marklund (29), respectively. Total glutathione (GSH) level was measured in muscle homogenate according to the method of Griffith (30).

Muscle and Mitochondrial CoQ9 and CoQ10 content: Frozen muscle tissues (100 mg) were homogenized in $100 \mu$ l of 2-propanol by Thurax dissecation. $100 \mu 1$ of muscle homogenate or $100 \mu 1$ of pure mitochondrial preparation were solubilized in $400 \mu \mathrm{l}$ of 2-propanol for the step extraction, $50 \mu 1$ of the 
supernatant were injected in the system reverse-phase HPLC with electrochemical detection for a simultaneous detection of reduced and oxidized forms of CoQ9 and CoQ10 by on the same run (31). Results were expressed as nmol/g of tissue. The redox state was expressed as [reduced form]/[oxidized form].

NADt, NADH and NAD ${ }^{+}$content assay: Content in total NAD (NADt), its reduced (NADH) and oxidized $\left(\mathrm{NAD}^{+}\right)$forms, were assayed on frozen muscle homogenates using the NAD-NADH Assay Kit (Abcam plc, Cambridge, UK).

NADPH oxidase and xanthine oxidase hydrogen peroxide production: Muscle homogenates in Krebs buffer were incubated at $37^{\circ} \mathrm{C}$ for $30 \mathrm{~min}$ in the presence or absence of DPI $(1 \mu \mathrm{M})$ or allopurinol $(90 \mu \mathrm{M})$, the inhibitors of NADPH oxidase and xanthine oxidase, respectively. $\mathrm{H}_{2} \mathrm{O}_{2}$ was assessed after adding excess NADPH $(100 \mathrm{mM})$ or xanthine $(1 \mathrm{mM})$, the substrates for NADPH oxidase and xanthine oxidase, respectively, using the probe Amplex Red in the presence of horseradish peroxidase (spectrofluorimeter SAFAS FLX-XENIUS, Monaco). Blank cells are used for measuring background and all reactions for a given sample are monitored simultaneously and calibrated against an $\mathrm{H}_{2} \mathrm{O}_{2}$ calibration curve. Xanthine oxidase protein was finally assessed on muscle homogenates by western blotting.

Real-time quantitative RT-PCR analysis: Total RNA was extracted with the TRIzol Reagent (Invitrogen, Life Technologies, Saint-Aubin, France). Levels of mRNA were assessed by reverse transcription-polymerase chain reaction (RT-PCR). Total RNAs were extracted using Tri-Reagent according to the manufacturer's instructions transcriptase (Invitrogen). RNA sample's concentration and integrity were determined by absorbance measurement at $260 \mathrm{~nm}$ electrophoresis on agarose gel respectively. One $\mu \mathrm{g}$ of total RNA was reverse-transcribed using SuperScript III reverse transcriptase (Invitrogen) before real time quantitative polymerase chain reaction ( $\mathrm{qPCR}$ ) using the Rotor-Gene SYBR Green PCR master mix on a Rotor- Gene Q system (Qiagen, Courtaboeuf, France). Relative mRNA concentrations were determined using a standard curve made from a mixture of all native cDNA and serial dilutions and using Hypoxanthine-guanine phosphoribosyltransferase (Hprt) as housekeeping gene. Specific PCR primers were ordered from Sigma. Primer Sequences are available upon request.

\section{Analysis of muscle mitochondrial pellets}


Muscle isolated mitochondria preparation: Gastrocnemius and quadriceps were quickly removed from overnight fasted animals ( $\mathrm{n}=10$ per group) euthanized as described above. Fresh muscles were kept at $4^{\circ} \mathrm{C}$ in a preservation solution $\left(\mathrm{CaK}_{2}\right.$ EGTA $1.9 \mathrm{mM}$; $\mathrm{K}_{2}$ EGTA $8.1 \mathrm{mM}$; imidazole $20 \mathrm{mM}$, DTT $0.5 \mathrm{mM}$; $\mathrm{MgCl}_{2} 9.5 \mathrm{mM}$; MES $53.3 \mathrm{mM}$; taurine $20 \mathrm{mM}$; ATP $2.5 \mathrm{mM}$; phosphocreatine $19 \mathrm{mM}$ ) until mitochondria were isolated as described in Capel et al. (32).

Mitochondrial hydrogen peroxide production: The production of mitochondria-derived $\mathrm{H}_{2} \mathrm{O}_{2}$ was assessed using the probe Amplex Red in the presence of horseradish peroxidase (spectrofluorimeter SAFAS FLX-XENIUS, Monaco) as described by Batandier et al. (33). Briefly, mitochondria (0.25 mg protein $/ \mathrm{mL})$ were incubated for $30 \mathrm{~min}$ at $37^{\circ} \mathrm{C}$ with substrates glutamate and malate ( 5 and $\left.2.5 \mathrm{mM}\right)$, and glutamate, malate and succinate $(5,2.5$ and $5 \mathrm{mM})$, with or without rotenone $(5 \mu \mathrm{M})$. Blank cells were used for measuring background and all reactions for a given sample were monitored simultaneously and calibrated against an $\mathrm{H}_{2} \mathrm{O}_{2}$ calibration curve.

Mitochondrial respiration: Mitochondria respiration rates were measured at $25^{\circ} \mathrm{C}$ using an oxygraph system (Oxytherm, Hansatech Instruments, UK) as described by Capel et al. (32). Briefly, oxygen consumption was assayed on $0.25 \mathrm{mg} / \mathrm{mL}$ of mitochondrial proteins using glutamate and malate (5 and $2.5 \mathrm{mM})$, succinate and rotenone $(5 \mathrm{mM}$ and $5 \mu \mathrm{M})$, glycerol-3Phosphate $(5 \mathrm{mM})$ and Antimycine A/Ascorbate/TMPD/DNP $(1.5 \mu \mathrm{M}, 2.5 \mathrm{mM}, 0.5 \mathrm{mM}$ and $75 \mu \mathrm{M}$, respectively) as substrates. State 3 was measured in the presence of respiratory substrates after the addition of $360 \mu \mathrm{M}$ of ADP (32). State 4 was assayed after addition of $60 \mu \mathrm{M}$ of atractyloside. Respiratory control ratio (RCR) was evaluated by dividing state 3 by state 4 .

Mitochondrial enzyme activities: Maximal activity of citrate synthase (CS), complex II and cytochrome c oxidase (COX) activities was assessed spectrophotometrically on muscle mitochondrial pellets, as described by Morio et al. (34). Complex I activity was assessed using the commercial kit Complex I Enzyme Activity Dipstick Assay Kit (MitoSciences \#MS130). An additional experimentation was performed on muscle homogenates from $\mathrm{C} 57 \mathrm{~B} / 6 \mathrm{~J}$ male mice in the presence or not of $0.6 \mathrm{mM}$ of $\mathrm{H}_{2} \mathrm{O}_{2}$. 
Six animals per group were fasted for 4 hours prior to an intraperitoneal injection of insulin $(0.75 \mathrm{mU} / \mathrm{g})$.

Mice were then anesthetized and euthanized 30 min after injection. Blood was collected in EDTA-tubes for assay of glucose and insulin concentration as described above. Gastrocnemius muscle was quickly removed, frozen in liquid nitrogen and stored at $-80^{\circ} \mathrm{C}$ until quantification of $\mathrm{Ser}^{473}$-pAkt and total Akt, as well as GLUT4,by western blotting.

\section{Ex vivo muscle response to insulin and glucose transport}

After an overnight fast, 6 animals per group were anaesthetized and euthanized by full blood redrawing from the abdominal aorta. Gastrocnemius was quickly removed, cut into strips.

To assess Akt phosphorylation, muscle strips were incubated in the absence or presence of various concentrations of insulin ( 1 and $50 \mathrm{nM})$ for 15 minutes. They were then rinsed and homogenized in ice-cold RIPA+ (50 mM HEPES, 150 mM NaCl, 10 mM EDTA, 10 mM NaPPi, 25 mM $\beta$-glycerophosphate, 100 $\mathrm{mM} \mathrm{NaF}, 10 \%$ glycerol (v/v), $2 \mathrm{mM}$ sodium-orthovanadate, $0.5 \% \mathrm{v} / \mathrm{v}$ protease inhibitor cocktail (SigmaAldrich, Saint-Louis, USA) and 1\% Triton X-100) and a standard western blot procedure was conducted to assess $\operatorname{Ser}^{473}$-pAkt and total Akt content.

To assess glucose transport, muscle strips were incubated in the absence or presence of various concentrations of insulin $(1$ and $50 \mathrm{nM})$ without or with $5 \mathrm{mM}$ of 2 -deoxy-D- $\left[{ }^{3} \mathrm{H}\right]$ glucose (DOG: $\left.0.5 \mu \mathrm{Ci} / \mathrm{ml}\right)$ as described by Dardevet et al. (35). They were then rinsed, blotted, weighed and digested in $1 \mathrm{M} \mathrm{NaOH}$ for $20 \mathrm{~min}$ at $80^{\circ} \mathrm{C}$ for radioactivity determination. Muscle glucose transport was calculated by dividing the radioactivity within the muscle by the specific activity of the DOG into the incubation medium; it was expressed as nmoles of DOG per milligram of muscle per $15 \mathrm{~min}$.

\section{$\underline{\text { Statistical analysis }}$}

Statistical analyses were performed using Statview, version 5.0 (SAS Institute Inc., Cary, NC, USA). Results are provided as means $\pm \mathrm{sd}$; except for the kinetic of RQ which is presented as mean \pm sem. Oneway analysis of variance (ANOVA) was used to examine the effect of strain and NAC on body composition, RQ, plasma metabolites and hormones, glucose transport, biochemical, western blot and qPCR assays. PLSD Fisher test was used for post hoc analyses. Results were considered significant at the $5 \%$ level. 


\section{Results}

Animals' body weight and composition, and energy metabolism

To better comprehend the differences between SAMP8 and SAMR1 strains, we first characterized the animals for whole body energy metabolism, metabolic flexibility and body composition. At 12 months of age, SAMP8 and SAMR1 had similar body weight, but muscle weights were 15-20\% lower in SAMP8 compared to SAMR1 ( $\mathrm{p}<0.0001$, Table 1). In addition, perirenal adipose tissue weight was 59\% lower in SAMP8 compared to SAMR1 whereas liver weight was similar $(\mathrm{p}<0.05$, Table 1$)$.

Table 1. Animal characteristics

\begin{tabular}{|c|c|c|c|c|}
\hline & SAMP8 & SAMP8 NAC & SAMR1 & P value \\
\hline Body weight (g) & $32.7 \pm 5.6$ & $27.8 \pm 5.0$ & $32.2 \pm 3.3$ & $\begin{array}{l}\text { Strain: } p=0.666 \\
\text { NAC: } p=0.01\end{array}$ \\
\hline Gastrocnemius mass (g) & $109 \pm 19$ & $91 \pm 7$ & $137 \pm 18$ & $\begin{array}{l}\text { Strain: } p<0.0001 \\
\text { NAC: } p<0.01\end{array}$ \\
\hline Quadriceps mass (g) & $168 \pm 14$ & $151 \pm 16$ & $198 \pm 16$ & $\begin{array}{l}\text { Strain: } p<0.0001 \\
\text { NAC: } p=0.887\end{array}$ \\
\hline Liver (g) & $1.30 \pm 0.23$ & $1.52 \pm 0.24$ & $1.22 \pm 0.20$ & $\begin{array}{l}\text { Strain: } \mathrm{p}=0.146 \\
\text { NAC: } \mathrm{p}<0.01\end{array}$ \\
\hline $\begin{array}{l}\text { Perirenal adipose tissue } \\
(\mathrm{g})\end{array}$ & $0.96 \pm 0.70$ & $1.36 \pm 0.70$ & $2.36 \pm 0.99$ & $\begin{array}{l}\text { Strain: } \mathrm{p}<0.05 \\
\text { NAC: } \mathrm{p}=0.616\end{array}$ \\
\hline \multicolumn{5}{|c|}{ Plasma concentrations in the fasted state } \\
\hline Insulin (ng/ml) & $0.30 \pm 0.12$ & $0.43 \pm 0.19$ & $0.33 \pm 0.12$ & $\begin{array}{l}\text { Strain: } p=0.933 \\
\text { NAC: } p=0.240\end{array}$ \\
\hline Glucose $(\mathrm{g} / \mathrm{l})$ & $0.61 \pm 0.11$ & $0.54 \pm 0.12$ & $0.87 \pm 0.11$ & $\begin{array}{l}\text { Strain: } \mathrm{p}<0.01 \\
\text { NAC: } \mathrm{p}=0.177\end{array}$ \\
\hline Triglycerides $(\mathrm{g} / \mathrm{l})$ & $0.81 \pm 0.08$ & $1.31 \pm 0.28$ & $1.09 \pm 0.23$ & $\begin{array}{l}\text { Strain: } \mathrm{p}=0.104 \\
\text { NAC: } \mathrm{p}=0.122\end{array}$ \\
\hline $\begin{array}{l}\text { Non-esterified fatty acids } \\
(\mu \mathrm{mol} / \mathrm{l})\end{array}$ & $679 \pm 144$ & $730 \pm 105$ & $500 \pm 117$ & $\begin{array}{l}\text { Strain: } p<0.01 \\
\text { NAC: } p<0.001\end{array}$ \\
\hline Glycerol $(\mu \mathrm{mol} / \mathrm{l})$ & $517 \pm 100$ & $518 \pm 56$ & $531 \pm 96$ & $\begin{array}{l}\text { Strain: } \mathrm{p}=0.891 \\
\text { NAC: } \mathrm{p}=0.692\end{array}$ \\
\hline \multicolumn{5}{|c|}{ Plasma concentrations 30 min after intraperitoneal injection of insulin* } \\
\hline Insulin (ng/ml) & $0.62 \pm 0.24$ & $0.63 \pm 0.16$ & $0.83 \pm 0.18$ & $\begin{array}{l}\text { Strain: } p<0.01 \\
\text { NAC: } p=0.958\end{array}$ \\
\hline Glucose $(\mathrm{g} / \mathrm{l})$ & $0.53 \pm 0.03$ & $0.33 \pm 0.10$ & $0.34 \pm 0.09$ & $\begin{array}{l}\text { Strain: } p<0.01 \\
\text { NAC: } p<0.01\end{array}$ \\
\hline Triglycerides $(\mathrm{g} / \mathrm{l})$ & $0.51 \pm 0.09$ & $0.74 \pm 0.18$ & $0.70 \pm 0.12$ & $\begin{array}{l}\text { Strain: } p=0.062 \\
\text { NAC: } p=0.120\end{array}$ \\
\hline $\begin{array}{l}\text { Non-esterified fatty acids } \\
(\mu \mathrm{mol} / \mathrm{l})\end{array}$ & $648 \pm 174$ & $629 \pm 182$ & $557 \pm 131$ & $\begin{array}{l}\text { Strain: } \mathrm{p}=0.211 \\
\text { NAC: } \mathrm{p}=0.327\end{array}$ \\
\hline Glycerol $(\mu \mathrm{mol} / \mathrm{l})$ & $324 \pm 43$ & $306 \pm 51$ & $351 \pm 43$ & $\begin{array}{l}\text { Strain: } p=0.307 \\
\text { NAC: } p=0.920\end{array}$ \\
\hline
\end{tabular}


To explore whether these differences in body composition were associated with alterations in energy metabolism, 24h energy expenditure and respiratory quotient (RQ) were measured using indirect calorimetry. Energy expenditure over $24 \mathrm{~h}$ was similar between the two strains $(49.4 \pm 4.9$ vs. $54.0 \pm 4.5$ $\mathrm{kJ} / 24 \mathrm{~h}$, for SAMP8 and SAMR1, respectively, $\mathrm{p}=0.261$ ). RQ over $24 \mathrm{~h}$ was also similar between the two strains $(0.820 \pm 0.037$ vs. $0.807 \pm 0.017$, for SAMP8 and SAMR1, respectively, $\mathrm{p}=0.930)$. However, $24 \mathrm{~h}$ kinetics evidenced that RQ of SAMP8 tended to be lower in the fasted state and higher in the fed and active phases compared to SAMR1, suggesting a higher metabolic flexibility in SAMP8 animals compared to SAMR1 (Figure 1).

Figure 1. Respiratory quotient kinetics over $24 \mathrm{~h}$ of SAMP8 and SAMR1 (n=4 per group).

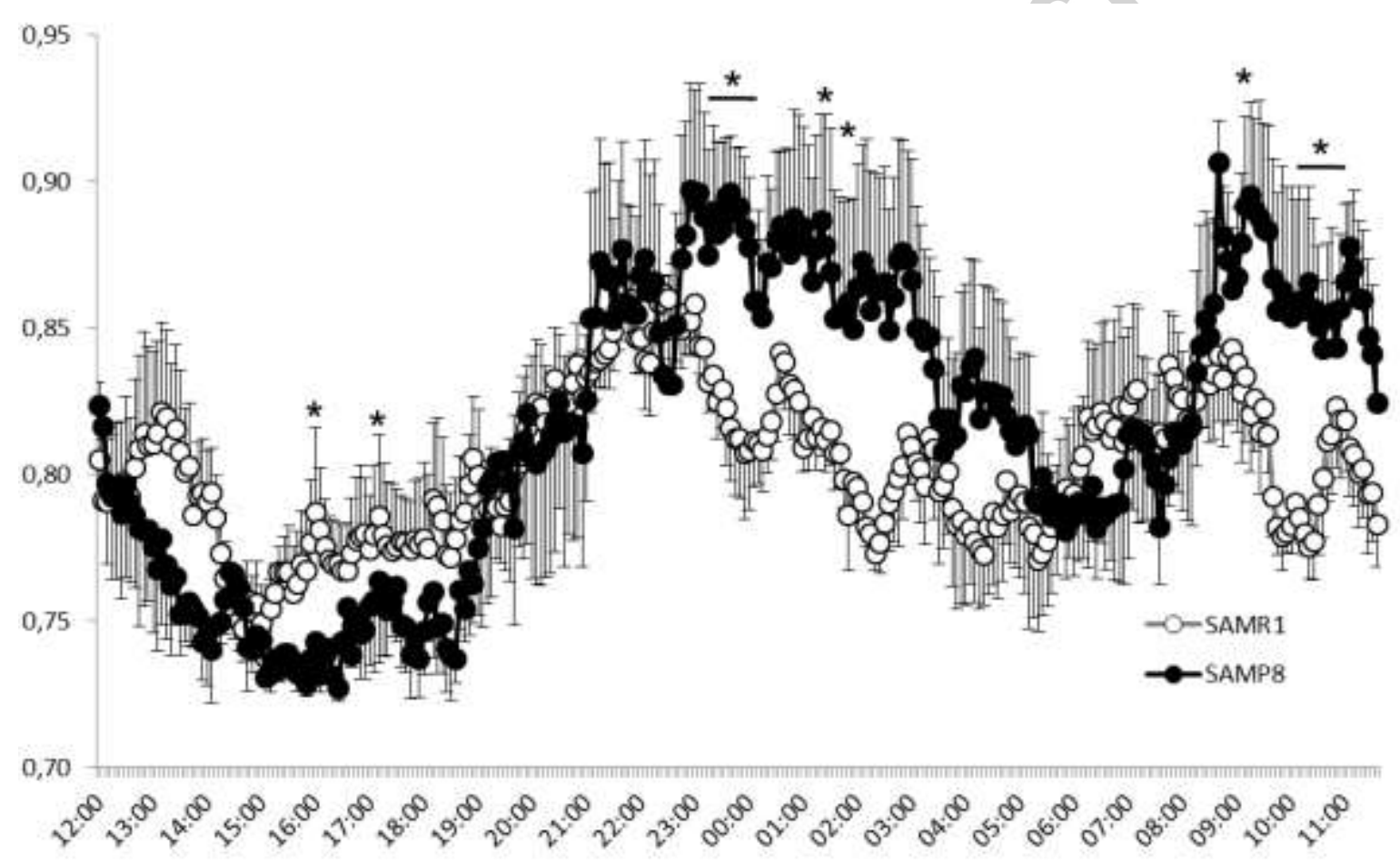

\section{Oxidative stress is higher in skeletal muscle of SAMP8 compared to SAMR1}

As hypothesized in our study, we validated that muscles of SAMP8 mice are characterized by a higher oxidative stress in comparison to SAMR1. Muscle content in carbonylated proteins was two-fold higher in 
SAMP8 compared to SAMR1 ( $\mathrm{p}<0.01$, Figure 2A). This was associated with a lower glutathione content $(\mathrm{p}<0.001$, Figure $2 \mathrm{~B})$ and a $21 \%$ higher glutathione peroxidase activity in muscle of SAMP8 compared to SAMR1 ( $\mathrm{p}<0.05$, Figure 3A). Muscle content in CoQ9 was similar between strains (Figure 2C) but that of CoQ10 was $120 \%$ higher in SAMP8 compared to SAMR1 ( $<<0.01$, Figure 2D). Catalase and total SOD activity were similar between the two strains (Figure 3B and 3D, respectively). However, Mn-SOD activity was $25 \%$ lower in SAMP8 compared to SAMR1 ( $p<0.05$, Figure 3C). Strain differences in gene expression of these enzymes corroborated differences in maximal activities, except for Mn-SOD for which mRNA content was higher in SAMP8 compared to SAMR1 ( $\mathrm{p}<0.01$, Table 2).

Figure 2. Muscle content in (A) carbonylated protein ( $n=4$ per group), (B) glutathione (GSH), $(n=10$ per group) (C) total CoQ9 and (D) total CoQ10 ( $\mathrm{n}=10$ per group) in SAMP8, SAMP8 receiving $\mathrm{N}-$ acetylcysteine (SAMP8-NAC) and SAMR1.
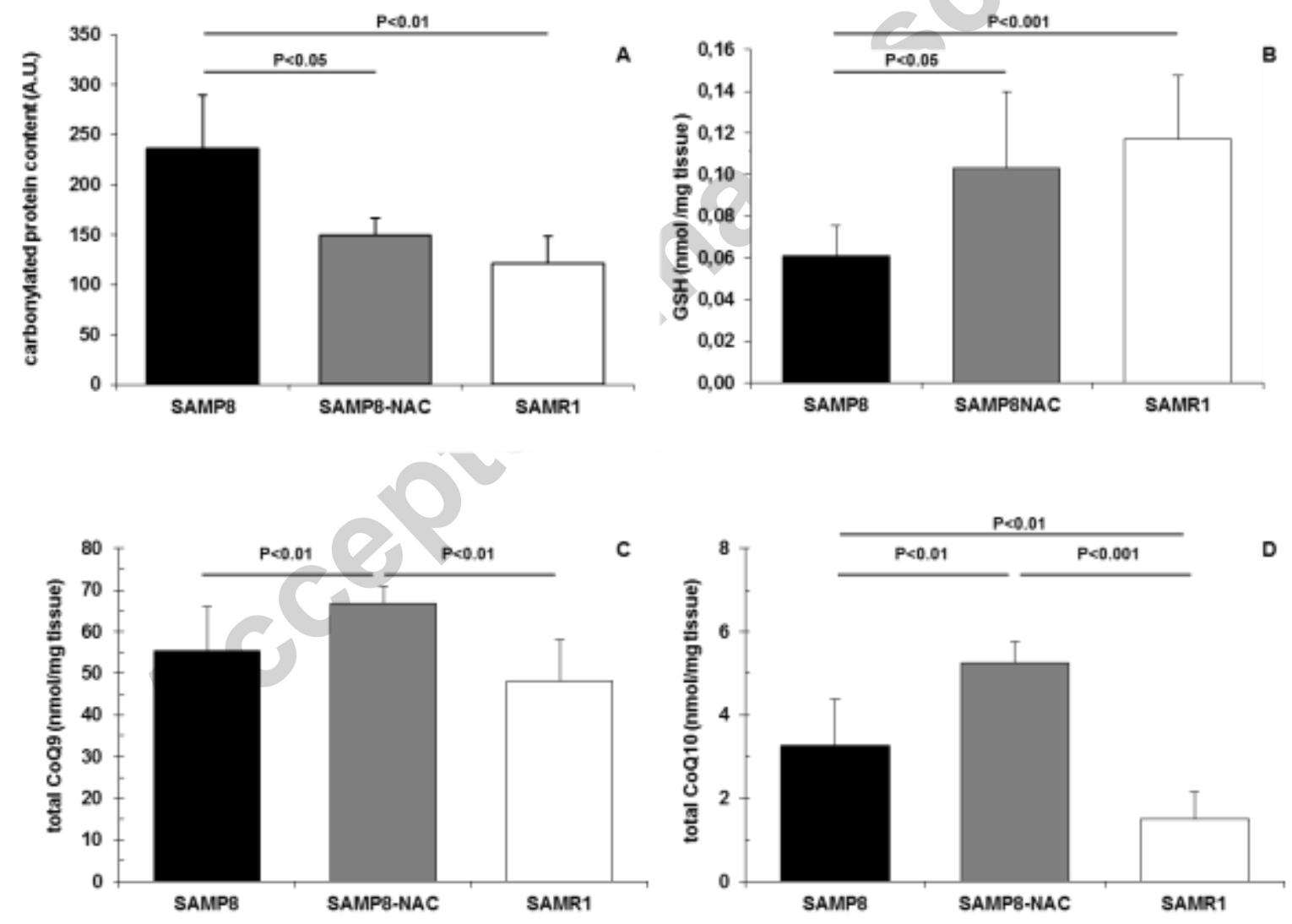
Figure 3. Maximal activity of muscle antioxidant enzymes (A) glutathione peroxidase (G

PX); (B) total superoxide dismutase (tSOD); (C) manganese SOD (Mn-SOD); (D) catalase in SAMP8, SAMP8 receiving $\mathrm{N}$-acetylcysteine (SAMP8-NAC) and SAMR1 ( $\mathrm{n}=10$ per group).
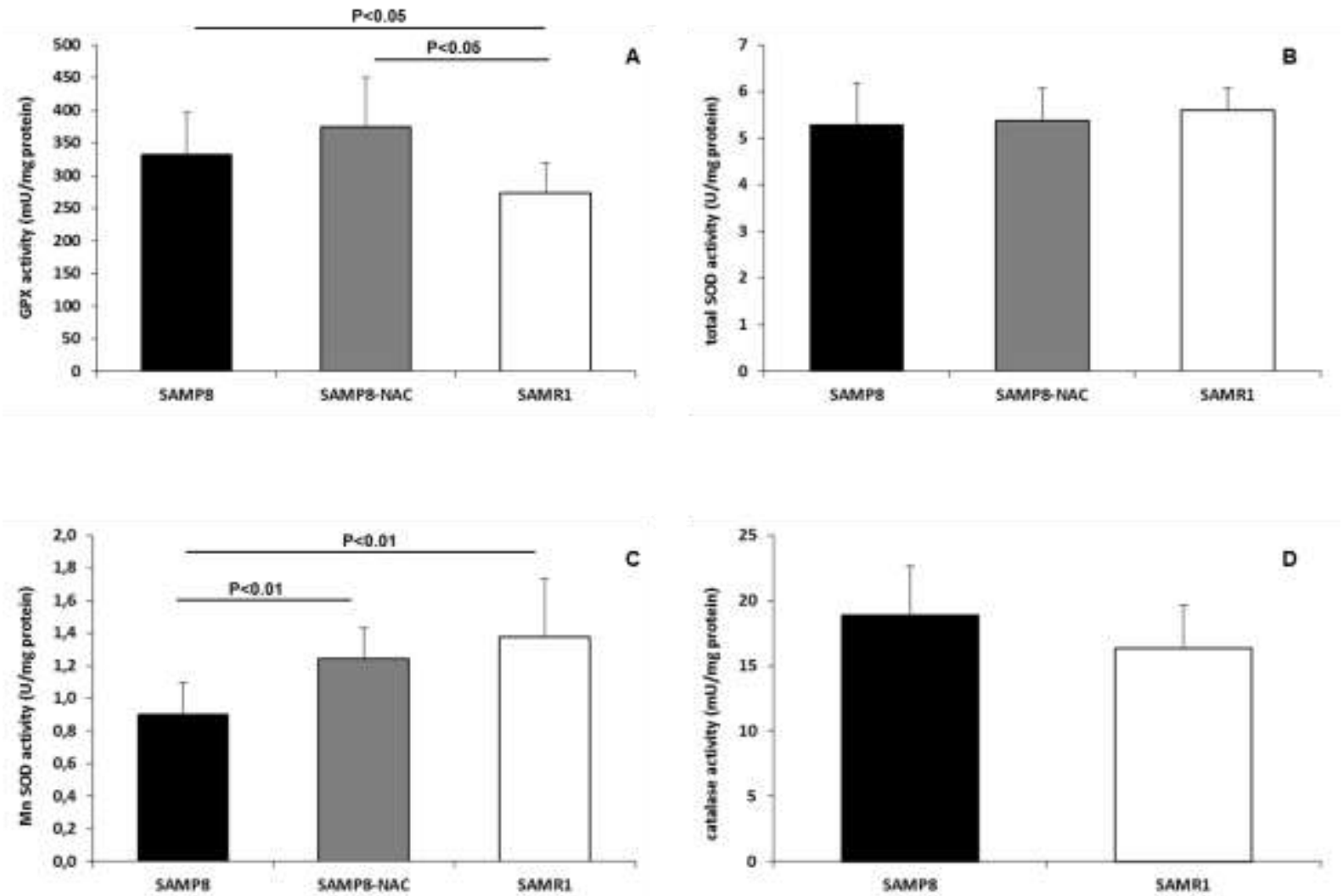

Oxidative stress in skeletal muscle of SAMP8 is associated to enhanced xanthine oxidase activity compared $\underline{\text { to } S A M R 1}$

We next investigated whether ROS production was increased in muscle of SAMP8 mice, and aimed at identifying the main source which could be related to the higher oxidative stress. $\mathrm{H}_{2} \mathrm{O}_{2}$ production by both NADPH oxidase and mitochondria was similar between the two strains (Figure 4A and 4B). By contrast, $\mathrm{H}_{2} \mathrm{O}_{2}$ production by xanthine oxidase was $70 \%$ higher in SAMP8 compared to SAMR1 ( $<0.05$, Figure $4 \mathrm{C}$ ). Increased xanthine oxidase activity was corroborated by strain differences in gene expression of the enzyme, the latter being 55 fold higher in SAMP8 compared to SAMR1 ( $\mathrm{p}<0.0001$, Table 2), and by strain differences in muscle protein content of the enzyme, the latter being 30\% higher in SAMP8 compared to SAMR1 ( $<<0.05$, Figure 5A). 
Figure 4. Main sources of reactive oxygen species in muscle of SAMP8 and SAMR1 from (A) mitochondrial respiratory chain using glutamate/malate (GM) or glutamate/malate/succinate (GMS) as substrates in the absence or presence of rotenone; (B) NADPH oxidase; (C) xanthine oxidase; (D) complex I activity in control conditions and in the presence of hydrogen peroxide $(0.6 \mathrm{mM})(\mathrm{n}=10$ per group).
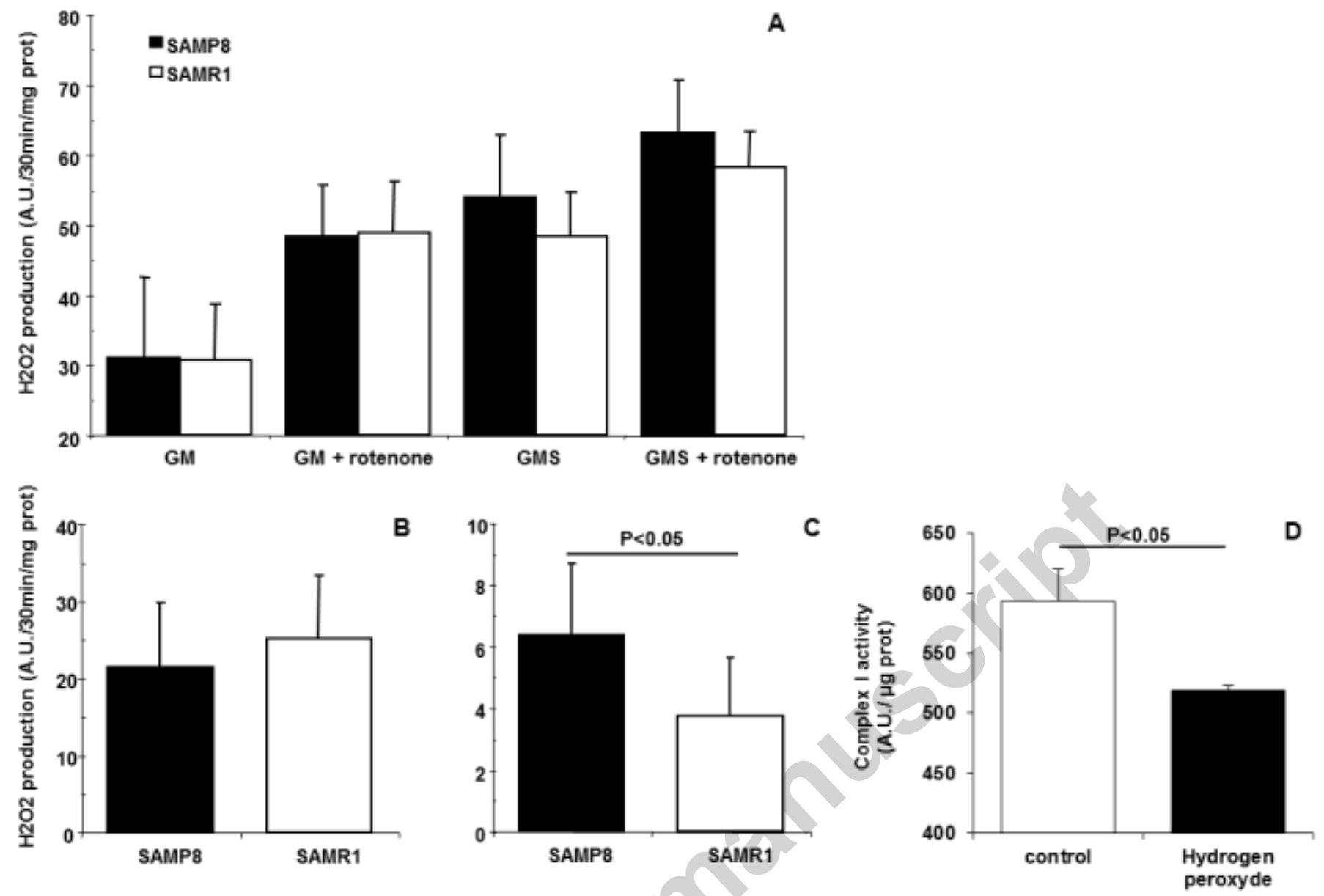

Figure 5. Total muscle content in (A) xanthine oxidase and (B) GLUT4 in SAMP8, SAMP8 receiving Nacetylcysteine (SAMP8-NAC) and SAMR1 ( $\mathrm{n}=8$ per group).

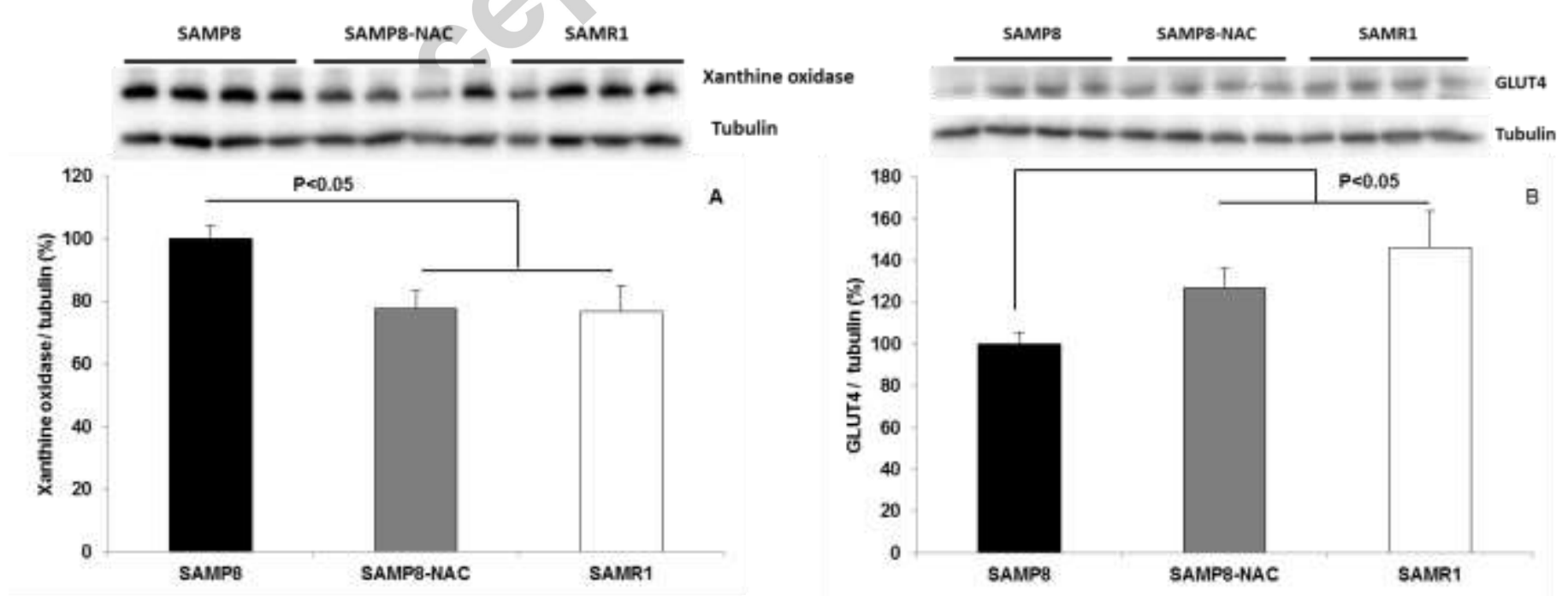


Table 2. Muscle gene expression of key proteins. Results are expressed relative to the housekeeping gene Hypoxanthine-guanine phosphoribosyltransferase (Hprt),

\begin{tabular}{|c|c|c|c|c|}
\hline 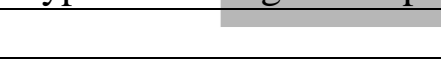 & SAMP8 & SAMP8-NAC & SAMR1 & $\mathrm{P}$ value \\
\hline \multicolumn{5}{|l|}{ Pro-oxidant enzyme } \\
\hline Xanthine oxidase & $2.19 \pm 1.00$ & $2.06 \pm 1.49$ & $0.04 \pm 0.02$ & $\begin{array}{l}\text { Strain : } p<0.0001 \\
\text { NAC }: p=0.298\end{array}$ \\
\hline \multicolumn{5}{|l|}{ Anti-oxidant enzymes } \\
\hline Glutathione peroxidase 1 & $10.88 \pm 2.28$ & $15.45 \pm 2.12$ & $7.32 \pm 2.08$ & $\begin{array}{l}\text { Strain }: p<0.05 \\
\text { NAC }: p<0.0001\end{array}$ \\
\hline Glutathione peroxidase 4 & $0.625 \pm 0.108$ & $0.802 \pm 0.230$ & $0.769 \pm 0.175$ & $\begin{array}{l}\text { Strain }: p=0.308 \\
\text { NAC }: p=0.142\end{array}$ \\
\hline Glutathione reductase & $0.621 \pm 0.153$ & $0.663 \pm 0.286$ & $0.749 \pm 0.212$ & $\begin{array}{l}\text { Strain }: p=0.488 \\
\text { NAC }: p=0.798\end{array}$ \\
\hline Catalase & $0.484 \pm 0.255$ & $0.376 \pm 0.140$ & $0.545 \pm 0.174$ & $\begin{array}{l}\text { Strain }: p=0.737 \\
\text { NAC }: p=0.073\end{array}$ \\
\hline Superoxide dismutase 1 & $0.936 \pm 0.263$ & $0.783 \pm 0.229$ & $0.897 \pm 0.220$ & $\begin{array}{l}\text { Strain }: p=0.119 \\
\text { NAC }: p=0.299\end{array}$ \\
\hline Superoxide dismutase 2 & $0.851 \pm 0.310$ & $0.738 \pm 0.224$ & $0.814 \pm 0.151$ & $\begin{array}{l}\text { Strain : } p=0.900 \\
\text { NAC }: p=0.267\end{array}$ \\
\hline $\begin{array}{l}\text { Mn-Superoxide } \\
\text { dismutase }\end{array}$ & $1.091 \pm 0.605$ & $0.808 \pm 0.489$ & $0.602 \pm 0.244$ & $\begin{array}{l}\text { Strain : } p<0.05 \\
\text { NAC }: p=0.272\end{array}$ \\
\hline \multicolumn{5}{|c|}{ Regulation of mitochondrial biogenesis and functioning } \\
\hline PGC-1alpha & $0.710 \pm 0.240$ & $0.646 \pm 0.224$ & $0.760 \pm 0.354$ & $\begin{array}{l}\text { Strain }: p=0.619 \\
\text { NAC }: p=0.708\end{array}$ \\
\hline PGC-1beta & $8.63 \pm 2.37$ & $7.27 \pm 3.42$ & $6.85 \pm 2.51$ & $\begin{array}{l}\text { Strain : } p=0.304 \\
\text { NAC }: p=0.524\end{array}$ \\
\hline NRF1 & $1.005 \pm 0.265$ & $1.041 \pm 0.323$ & $1.069 \pm 0.303$ & $\begin{array}{l}\text { Strain : } p=0.708 \\
\text { NAC }: p=0.471\end{array}$ \\
\hline NRF2 & $0.789 \pm 0.172$ & $0.639 \pm 0.202$ & $0.938 \pm 0.244$ & $\begin{array}{l}\text { Strain }: p=0.200 \\
\text { NAC }: p<0.05\end{array}$ \\
\hline Tfam & $0.971 \pm 0.426$ & $0.918 \pm 0.557$ & $1.054 \pm 0.456$ & $\begin{array}{l}\text { Strain }: p=0.598 \\
\text { NAC }: p=0.800\end{array}$ \\
\hline PPARalpha & $0.769 \pm 0.322$ & $0.753 \pm 0.479$ & $0.747 \pm 0.398$ & $\begin{array}{l}\text { Strain : } p=0.665 \\
\text { NAC }: p=0.117\end{array}$ \\
\hline PPARbeta & $0.791 \pm 0.153$ & $1.131 \pm 0.470$ & $0.803 \pm 0.184$ & $\begin{array}{l}\text { Strain }: p=0.753 \\
\text { NAC }: p=0.06\end{array}$ \\
\hline \multicolumn{5}{|l|}{ Mitochondrial respiration } \\
\hline NDUFB6 & $7.05 \pm 1.94$ & $6.21 \pm 1.75$ & $7.19 \pm 1.31$ & $\begin{array}{l}\text { Strain }: p=0.690 \\
\text { NAC }: p=0.166\end{array}$ \\
\hline NDUFB8 & $0.510 \pm 0.173$ & $0.492 \pm 0.171$ & $0.734 \pm 0.214$ & $\begin{array}{l}\text { Strain : } p<0.05 \\
\text { NAC : } p=0.889\end{array}$ \\
\hline ND1 & $0.882 \pm 0.308$ & $0.801 \pm 0.257$ & $0.849 \pm 0.215$ & $\begin{array}{l}\text { Strain }: p=0.650 \\
\text { NAC }: p=0.943\end{array}$ \\
\hline ND6 & $0.759 \pm 0.290$ & $0.996 \pm 0.375$ & $0.776 \pm 0.335$ & $\begin{array}{l}\text { Strain : } p=0.883 \\
\text { NAC }: p=0.064\end{array}$ \\
\hline COXIV & $0.986 \pm 0.227$ & $0.958 \pm 0.210$ & $1.036 \pm 0.156$ & $\begin{array}{l}\text { Strain }: p=0.535 \\
\text { NAC }: p=0.545\end{array}$ \\
\hline $\begin{array}{l}\text { glycerol-3-phosphate } \\
\text { dehydrogenase } 2\end{array}$ & $0.725 \pm 0.295$ & $0.485 \pm 0.252$ & $0.864 \pm 0.321$ & $\begin{array}{l}\text { Strain : } p=0.370 \\
\text { NAC }: p<0.05\end{array}$ \\
\hline Malate dehydrogenase 1 & $0.818 \pm 0.254$ & $0.691 \pm 0.240$ & $0.766 \pm 0.224$ & $\begin{array}{l}\text { Strain : } p=0.427 \\
\text { NAC }: p=0.103\end{array}$ \\
\hline Malate dehydrogenase 2 & $0.640 \pm 0.094$ & $0.570 \pm 0.149$ & $.852 \pm 0.159$ & Strain $: \mathrm{p}=0.195$ \\
\hline
\end{tabular}




\begin{tabular}{|l|c|c|c|l|}
\hline & \multicolumn{2}{|l|}{} & & NAC $: \mathrm{p}=0.162$ \\
\hline Glucose uptake and glycolytic enzymes & & & \\
\hline GLUT4 & $8.04 \pm 1.34$ & $8.44 \pm 2.90$ & $7.83 \pm 2.12$ & $\begin{array}{l}\text { Strain }: \mathrm{p}=0.568 \\
\text { NAC }: \mathrm{p}=0.938\end{array}$ \\
\hline Phosphofructokinase & $0.870 \pm 0.288$ & $0.686 \pm 0.254$ & $0.834 \pm 0.251$ & $\begin{array}{l}\text { Strain }: \mathrm{p}=0.831 \\
\mathrm{NAC}: \mathrm{p}=0.270\end{array}$ \\
\hline $\begin{array}{l}\text { glyceraldehyde 3-P } \\
\text { dehydrogenase }\end{array}$ & $0.847 \pm 0.285$ & $0.738 \pm 0.249$ & $0.791 \pm 0.207$ & $\begin{array}{l}\text { Strain }: \mathrm{p}=0.370 \\
\text { NAC }: \mathrm{p}=0.207\end{array}$ \\
\hline $\begin{array}{l}\text { Pyruvate dehydrogenase } \\
\text { kinase 4 }\end{array}$ & $0.430 \pm 0.308$ & $1.172 \pm 0.738$ & $0.545 \pm 0.299$ & $\begin{array}{l}\text { Strain }: \mathrm{p}=0.547 \\
\text { NAC }: \mathrm{p}<0.05\end{array}$ \\
\hline
\end{tabular}

Six months of NAC treatment in SAMP8 reverses strain differences in skeletal muscle characteristics

In order to investigate the involvement of oxidative stress in skeletal muscle phenotype, both SAMR1 and SAMP8 mice were treated with the antioxydant NAC for 6 months. Since NAC treatment did not altered any of the characteristics of SAMR1, we chose to present only SAMP8-NAC results for clarity reasons. Except for both the gene expression and the activity of xanthine oxidase which remained unaffected by NAC treatment in muscle of SAMP8 (Table 2), strain differences in carbonylated protein content, glutathione content and Mn-SOD activity were reversed after NAC treatment so that characteristics of SAMP8-NAC were significantly different from SAMP8 and similar to SAMR1 (Figures 2 and 3). By contrast, NAC treatment significantly increased muscle content in CoQ9 and CoQ10 in SAMP8-NAC in comparison to SAMP8 and SAMR1 ( $<<0.01$; Figure 2C and 2D). Muscle content in CoQ9 and CoQ10 was respectively 20 and $60 \%$ higher in SAMP8-NAC compared to SAMP8, and 38 and $253 \%$ in SAMP8-NAC compared to SAMR1 ( $<<0.01$; Figure 2C and 2D).

\section{Muscle mitochondrial oxidative capacity is higher in SAMP8 compared to SAMRI but mitochondrial} content is similar between strains

We then examined whether oxidative stress had an impact on skeletal muscle mitochondrial function. ADPstimulated state 3 respiration rate of purified mitochondria with substrates of complexes I (glutamate/malate) was similar between groups, as well as with substrates of the glycerol-3phosphate shuttle (Table 3). By contrast, state 3 respiration rate was 22 and $24 \%$ higher with substrates of complexes II (succinate/rotenone) and IV (antimycine A/ascorbate/TMPD/DNP), respectively ( $\mathrm{p}<0.05$, Table 3). With all substrates, non-ADP stimulated state 4 respiration rate was significantly higher and RCR significantly lower in SAMP8 compared 
to SAMR1, thus evidencing mitochondrial uncoupling in SAMP8 $(\mathrm{p}<0.05$, Table 3). All differences were abolished in SAMP8 treated with NAC compared to SAMR1 (Table 3).

Table 3. Mitochondrial respiration rates using various substrates of the respiratory chain.

\begin{tabular}{|c|c|c|c|c|}
\hline & SAMP8 & SAMP8 NAC & SAMR1 & $\mathrm{P}$ value \\
\hline \multicolumn{5}{|l|}{ Glumate/Malate } \\
\hline State 3 (natom $\mathrm{O} / \mathrm{min} / \mathrm{mg}$ prot) & $234.2 \pm 70.5$ & $205.9 \pm 58.2$ & $220.1 \pm 39.7$ & $\begin{array}{l}\text { Strain: } p=0.282 \\
\text { NAC: } p=0.225\end{array}$ \\
\hline State 4 (natom $\mathrm{O} / \mathrm{min} / \mathrm{mg}$ prot) & $23.2 \pm 6.1$ & $13.0 \pm 4.7$ & $17.2 \pm 7.3$ & $\begin{array}{l}\text { Strain: } \mathrm{p}=0.05 \\
\text { NAC: } \mathrm{p}<0.001\end{array}$ \\
\hline RCR & $8.7 \pm 2.1$ & $13.0 \pm 3.5$ & $12.1 \pm 5.2$ & $\begin{array}{l}\text { Strain: } p<0.05 \\
\text { NAC: } p<0.01\end{array}$ \\
\hline \multicolumn{5}{|l|}{ Succinate/Rotenone } \\
\hline State 3 (natom $\mathrm{O} / \mathrm{min} / \mathrm{mg}$ prot) & $287.0 \pm 40.6$ & $241.3 \pm 76.3$ & $238.7 \pm 50.9$ & $\begin{array}{l}\text { Strain: } p<0.05 \\
\text { NAC: } p<0.05\end{array}$ \\
\hline State 4 (natom $\mathrm{O} / \mathrm{min} / \mathrm{mg}$ prot) & $50.7 \pm 13.3$ & $31.1 \pm 10.8$ & $31.8 \pm 15.2$ & $\begin{array}{l}\text { Strain: } \mathrm{p}<0.001 \\
\text { NAC: } \mathrm{p}<0.001\end{array}$ \\
\hline RCR & $6.3 \pm 1.5$ & $8.5 \pm 1.6$ & $8.5 \pm 3.8$ & $\begin{array}{l}\text { Strain: } p<0.05 \\
\text { NAC: } p<0.05\end{array}$ \\
\hline \multicolumn{5}{|l|}{ Glycerol-3 Phosphate } \\
\hline State 3 (natom $\mathrm{O} / \mathrm{min} / \mathrm{mg}$ prot) & $115.4 \pm 30.9$ & $N D$ & $99.4 \pm 39.1$ & Strain: $\mathrm{P}=0.820$ \\
\hline State 4 (natom $\mathrm{O} / \mathrm{min} / \mathrm{mg}$ prot) & $19.6 \pm 10.9$ & $N D$ & $7.0 \pm 6.7$ & Strain: $\mathrm{P}<0.05$ \\
\hline RCR & $6.9 \pm 2.6$ & $N D$ & $18.6 \pm 12.3$ & Strain: $\mathrm{P}<0.05$ \\
\hline \multicolumn{5}{|c|}{ Antimycine A/Ascorbate/TMPD/DNP } \\
\hline $\begin{array}{l}\text { Respiration rate } \\
\text { (natom } \mathrm{O} / \mathrm{min} / \mathrm{mg} \text { prot) }\end{array}$ & $928 \pm 139$ & $741 \pm 63$ & $746 \pm 158$ & $\begin{array}{l}\text { Strain: } \mathrm{p}<0.05 \\
\text { NAC: } \mathrm{p}<0.01\end{array}$ \\
\hline
\end{tabular}

$N D$, not determined.

In agreement with respiratory measurements, maximal activity of citrate synthase and complexes II and IV (cytochodrome c oxidase) was 18 to $30 \%$ higher on mitochondrial enriched fractions from SAMP8 compared to SAMR1 ( $\mathrm{P}<0.05$, Table 4). Furthermore, the ratio between cytochrome c oxidase and citrate synthase activities, which provides information about the mitochondrial oxidative capacity, tended to be higher in SAMP8 compared to SAMR1 $(+14 \%, \mathrm{p}=0.06$, Table 4). The difference reaches the level of significance when enzyme activities were measured on whole muscle homogenates (SAMP8 vs. SAMR1: $+12 \%, \mathrm{p}<0.05$, Table 4). By contrast and surprisingly, maximal activity of complex I was $22 \%$ lower in SAMP8 compared to SAMR1 ( $\mathrm{p}<0.05$, Table 4). To understand whether oxidative stress could be the cause, we found that hydrogen peroxide directly inhibits the catalytic activity of complex I, suggesting a functional inhibition of complex I by enhanced $\mathrm{H}_{2} \mathrm{O}_{2}$ production in muscle of SAMP8 (Figure 4D). Interestingly, differences in the maximal activity of citrate synthase and complexes I, II and IV, were abolished in SAMP8 
treated with NAC compared to SAMR1 (Table 4). In particular, maximal activity of complex I was 37\% higher in SAMP8-NAC compared to SAMP8 ( $\mathrm{p}<0.05)$, and was similar to SAMR1 (Table 4).

Table 4. Muscle mitochondrial content and maximal activity of key oxidative enzymes.

\begin{tabular}{|c|c|c|c|c|}
\hline & SAMP8 & SAMP8 NAC & SAMR1 & $\mathrm{P}$ value \\
\hline \multicolumn{5}{|c|}{ Muscle mitochondrial content } \\
\hline mtDNA/nDNA* & $0.555 \pm 0.018$ & $0.541 \pm 0.019$ & $0.545 \pm 0.017$ & $\begin{array}{l}\text { Strain: } p=0.350 \\
\text { NAC: } p=0.220\end{array}$ \\
\hline $\begin{array}{l}\text { Citrate synthase } \\
\text { (nmol/min/mg prot) }\end{array}$ & $0.260 \pm 0.041$ & $0.283 \pm 0.048$ & $0.283 \pm 0.026$ & $\begin{array}{l}\text { Strain: } p=0.183 \\
\text { NAC: } p=0.522\end{array}$ \\
\hline PGC-1 $\alpha /$ GAPDH (AU) & $3.55 \pm 0.39$ & $3.44 \pm 0.39$ & $3.27 \pm 0.34$ & $\begin{array}{l}\text { Strain: } p=0.101 \\
\text { NAC: } p=0.640\end{array}$ \\
\hline CREB-P/GAPDH (AU) & $0.46 \pm 0.16$ & $0.48 \pm 0.06$ & $0.57 \pm 0.09$ & $\begin{array}{l}\text { Strain: } p=0.414 \\
\text { NAC: } p=0.689\end{array}$ \\
\hline \multicolumn{5}{|c|}{ Muscle palmitate oxidation rate (nmol /g fresh tissue/min) } \\
\hline Total oxidation rate & $16.6 \pm 1.5$ & $28.2 \pm 5.1$ & $16.3 \pm 2.3$ & $\begin{array}{l}\text { Strain: } p=0.777 \\
\text { NAC: } p<0.001\end{array}$ \\
\hline $\begin{array}{l}\text { Mitochondrial } \\
\text { oxidation rate }\end{array}$ & $14.1 \pm 1.2$ & $23.5 \pm 3.4$ & $13.2 \pm 1.8$ & $\begin{array}{l}\text { Strain: } p=0.335 \\
\text { NAC: } p<0.001\end{array}$ \\
\hline $\begin{array}{l}\text { Peroxisomal oxidation } \\
\text { rate }\end{array}$ & $2.5 \pm 0.2$ & $4.7 \pm 1.8$ & $3.1 \pm 0.6$ & $\begin{array}{l}\text { Strain: } p<0.05 \\
\text { NAC: } p<0.05\end{array}$ \\
\hline \multicolumn{5}{|c|}{ Mitochondrial enriched fraction } \\
\hline $\begin{array}{l}\text { Citrate synthase } \\
\text { (nmol/min/mg prot) }\end{array}$ & $3.13 \pm 1.11$ & $2.29 \pm 0.37$ & $2.19 \pm 0.55$ & $\begin{array}{l}\text { Strain: } p=0.06 \\
\text { NAC: } p=0.06\end{array}$ \\
\hline $\begin{array}{l}\text { Complex I } \\
\text { (A.U.) }\end{array}$ & $305 \pm 62$ & $418 \pm 71$ & $393 \pm 58$ & $\begin{array}{l}\text { Strain: } p<0.05 \\
\text { NAC: } p<0.01\end{array}$ \\
\hline $\begin{array}{l}\text { Complex II } \\
\text { (nmol/min/mg prot) }\end{array}$ & $0.26 \pm 0.06$ & $0.21 \pm 0.03$ & $0.22 \pm 0.05$ & $\begin{array}{l}\text { Strain: } p=0.05 \\
\text { NAC: } p<0.05\end{array}$ \\
\hline $\begin{array}{l}\text { Cytochrome c oxidase } \\
\text { (nmol/min/mg prot) }\end{array}$ & $4.98 \pm 1.41$ & $3.54 \pm 0.42$ & $3.08 \pm 0.50$ & $\begin{array}{l}\text { Strain: } p<0.01 \\
\text { NAC: } p<0.05\end{array}$ \\
\hline $\begin{array}{l}\text { Cytochrome c oxidase/ } \\
\text { Citrate synthase }\end{array}$ & & $1.39 \pm 0.11$ & $1.37 \pm 0.18$ & $\begin{array}{l}\text { Strain: } p=0.06 \\
\text { NAC: } p<0.05\end{array}$ \\
\hline
\end{tabular}

* mtDNA/nDNA was assessed using the ratio between ND6 DNA content (mitochondria) and NDUF1 DNA content (nucleus). Similar results were obtained using the ratio between ND1 and NDUF1, ND1 and NDUFA2, ND6 and NDUFA2 (data not shown).

To further understand the mechanisms underlying the mitochondrial adaptations in muscle of SAMP8, we explored on the one hand, the alterations in mitochondrial CoQ content and on the other hand, the muscle mitochondrial content and the protein content of key regulators of mitochondrial biogenesis (Peroxisome proliferator-activated receptor gamma coactivator 1-alpha: PGC-1alpha, and phosphorylated cAMP response element-binding protein: CREB-P). 
Mitochondrial content in total CoQ9, the most representative CoQ in mouse mitochondria, was similar between strains and significantly reduced after NAC treatment in comparison to SAMP8 and SAMR1 $(\mathrm{p}<0.01$; figure 6A). Similar observations were made for CoQ10, which represent less than $10 \%$ of total CoQ (figure 6B). The ratio between reduced and oxidized forms for CoQ9 was similar between strains (Figure 6C), whereas it was significantly lower for CoQ10 in SAMP8 compared to SAMR1 and SAMP8NAC $(\mathrm{p}<0.05$; figure $6 \mathrm{D})$.

Figure 6. Total muscle content in (A) CoQ9, (B) CoQ10, (C) CoQ9H2/CoQ9 and (D) CoQ10H2/CoQ10 in SAMP8, SAMP8 receiving N-acetylcysteine (SAMP8-NAC) and SAMR1 ( $\mathrm{n}=10$ per group).
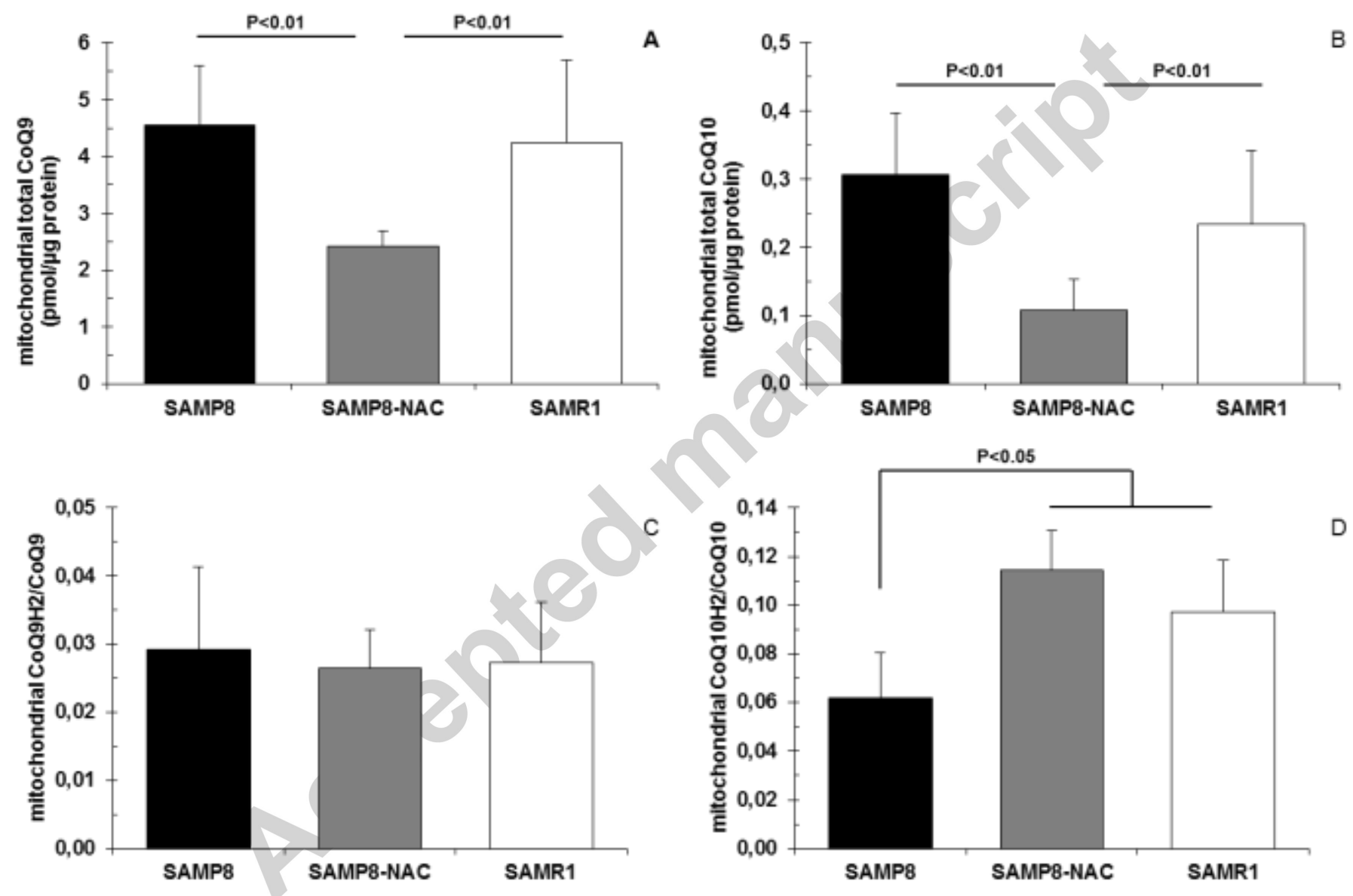

On muscle homogenates, maximal activity of citrate synthase as well as mtDNA/nDNA ratio, and PGC1alpha and CREB-P content (Table 4), were similar between strains, suggesting that muscle mitochondrial content was similar between strains and unaffected by NAC treatment. Supporting this conclusion, gene expression of key proteins involved in the regulation of mitochondrial biogenesis and function (e.g. PGC- 
1alpha, PGC-1beta, Nuclear respiratory factor 1: NRF1, and Mitochondrial transcription factor A: Tfam) was similar between SAMP8 and SAMR1, and not affected by NAC treatment (Table 2). Only NRF2 (Nuclear respiratory factor 2) mRNA content was significantly decreased after NAC treatment in SAMP8 $(\mathrm{p}<0.05$, Table 2).

\section{Muscle mitochondrial fatty acid oxidative capacity is similar between strains but increased after NAC}

\section{$\underline{\text { treatment }}$}

Since intrinsic adaptations were observed in muscle mitochondria of SAMP8 mice, we questioned whether these could impact on their fatty acid oxidative capacity. Maximal capacity of muscle homogenates to oxidize palmitate was similar between SAMP8 and SAMR1 (Table 2). Only peroxisomal activity was $20 \%$ lower in SAMP8 compared to SAMR1 $(\mathrm{p}<0.05$, Table3). Strikingly, SAMP8 treated with NAC demonstrated a $70-73 \%$ higher total palmitate oxidative capacity compared to the two other groups $(\mathrm{p}<0.001$, Table3). This was due to a significant increase in both mitochondrial and peroxisomal oxidative capacities $(\mathrm{p}<0.001$ and $\mathrm{p}<0.05$, respectively, Table3). Interestingly, gene expression of PDK4 (Pyruvate dehydrogenase kinase isozyme 4), which inhibits the pyruvate dehydrogenase complex and enhances the mitochondrial fatty acid oxidation, was 97 and 172\% higher in SAMP8-NAC compared to SAMR1 and SAMP8, respectively ( $\mathrm{p}<0.05$, Table 2$)$. In addition, gene expression of PPARbeta (Peroxisome proliferatoractivated receptor beta), which upregulates PDK4 mRNA (35), tended to be higher in SAMP8-NAC compared to the two other groups $(\mathrm{p}=0.06$, Table 2$)$.

$\underline{\text { In vivo muscle Akt phosphorylation was higher in response to insulin stimulation in SAMP8 compared to }}$

$\underline{\text { SAMR1 }}$

SAMP8 were characterized by a $30 \%$ lower fasting plasma glucose concentration compared to SAMR1 $(\mathrm{p}<0.05$, Table 1), whereas fasting plasma insulin was similar between the two strains (Table 1). We thus hypothesized that the oxidative stress characterizing this strain was associated with enhanced insulin response and glucose transport in skeletal muscle. In vivo insulin injection induced a $43 \%$ higher phosphorylation rate of Akt in skeletal muscle of SAMP8 compared to SAMR1 ( $\mathrm{p}<0.05$, Figure 7A). These strain differences were abolished in SAMP8 treated with NAC $(\mathrm{p}<0.01$; Figure 7A). 


\section{ACCEPTED MANUSCRIPT}

Muscle gene expression of key enzymes involved in glucose metabolism was similar between strains and unaffected by NAC treatment (Table 2). By contrast, GLUT4 content was $32 \%$ lower in skeletal muscle of SAMP8 compared to SAMR1 $(\mathrm{p}<0.05$, Figure 5B) and these strain differences were abolished in SAMP8 treated with NAC $(\mathrm{p}<0.05$; Figure 5B).

Ex vivo incubation of fresh muscle strips with increasing doses of insulin gave similar results to in vivo observations (Figure 7B). Indeed, muscle Akt phosphorylation was 135 and 77\% higher in SAMP8 compared to SAMR1 in the presence of 1 and $5 \mathrm{nM}$ of insulin, respectively $(\mathrm{p}<0.01$, Figure $7 \mathrm{~B})$. However, the difference between strains was not significant at the two extreme doses of insulin, i.e. 0.2 and $50 \mathrm{nM}$ of insulin. Contrasting with those latter observations, ex vivo glucose uptake measured on fresh muscle strips was $26 \%$ higher in SAMP8 compared to SAMR1 in the presence of $0.2 \mathrm{nM}$ of insulin ( $<<0.001$, Figure $7 \mathrm{C}$ ). It was still 18 to $11 \%$ higher in SAMP8 compared to SAMR1 in response to 1 to $50 \mathrm{nM}$ of insulin $(\mathrm{p}<0.05$, Figure 7C). Finally, glucose uptake expressed according to Akt phosphorylation state was systematically $15 \%$ higher in muscle of SAMP8 compared to SAMR1 (Figure 7D). 
Figure 7. In vivo muscle (A) Akt phosphorylation in response to insulin intraperitoneal injection $(0.75 \mathrm{mU} / \mathrm{g})$ and ex vivo muscle (B) Akt phosphorylation, (C) deoxyglucose transport and (D) relationship between Akt phosphorylation and deoxyglucose transport, in response to increasing concentration of insulin (Ins $=0.2,1,5$ and $50 \mathrm{nM}$ ) in SAMP8, SAMP8 receiving N-acetylcysteine (SAMP8-NAC) and SAMR1 (n=6 per group).
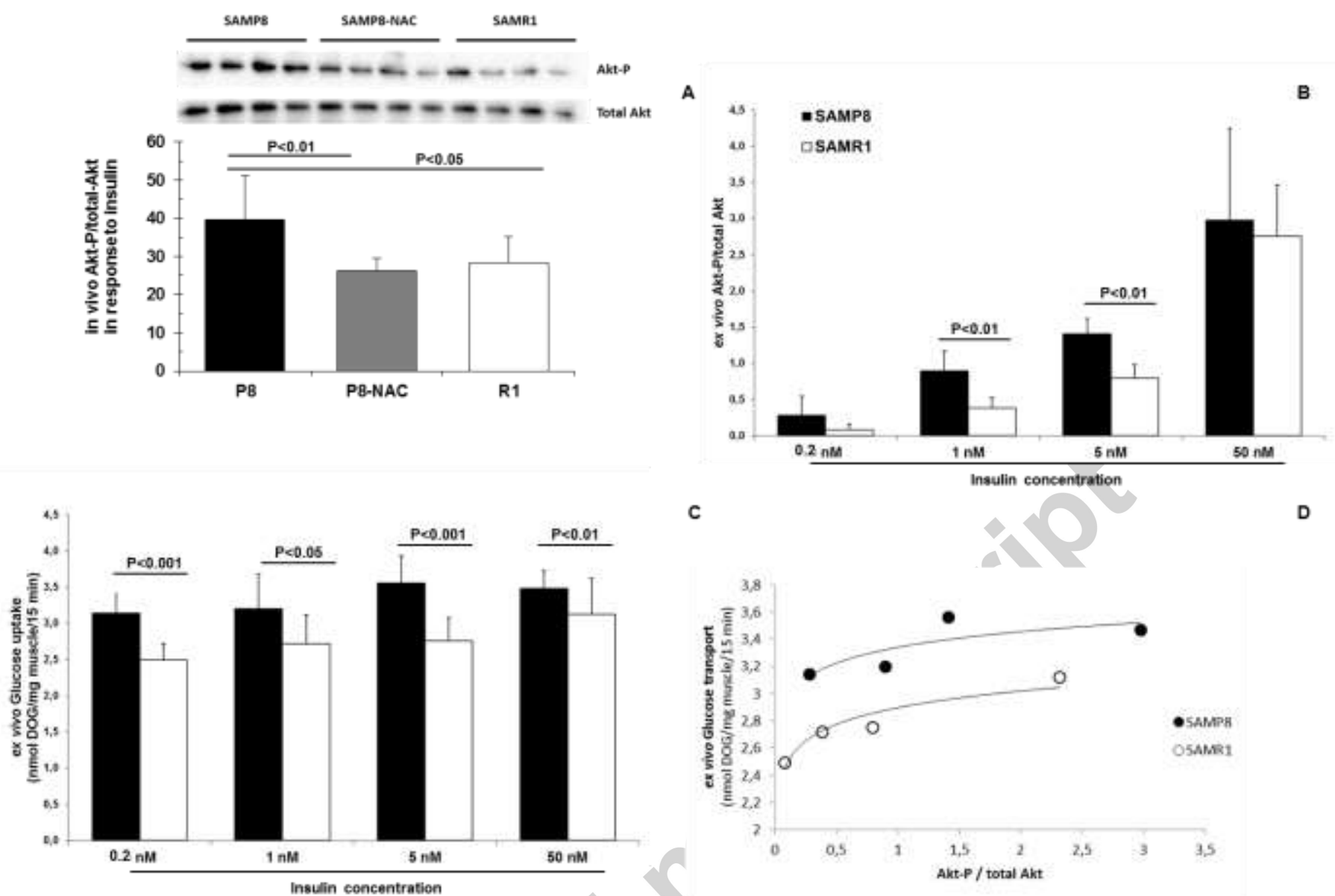

Intriguingly in these ex vivo experimentations, strain differences in Akt phosphorylation and glucose uptake were not corrected in SAMP8 treated with NAC, although they were abolished in vivo. Hence, Akt phosphorylation and glucose uptake measured on muscle strips were similar between SAMP8-NAC and SAMP8 for all conditions, and significantly higher than SAMR1 values (data not shown). Xanthine oxidase is an alternate form of the same gene product of xanthine dehydrogenase, which is the precursor. In addition, xanthine oxidase and xanthine dehydrogenase are both able to produce hydrogen peroxide (36). Since NAC did not alter xanthine dehydrogenase/oxidase gene expression which was still 50 fold higher in NAC-treated SAMP8 compared to SAMR1 ( $\mathrm{p}<0.0001$, Table 2$)$, preserved activity of the enzymes may have resulted in 
acute oxidative stress during the ex vivo incubation thus maintaining high levels of Akt phosphorylation and glucose uptake.

\section{ACCEPTED MANUSCRIPT}

Skeletal muscle of SAMP8 shows lower content in NADt, NADH and NAD ${ }^{+}$, but similar NADH/NAD ${ }^{+}$ratio compared to SAMRI

To finish, we examined whether high muscle glucose uptake was associated with enhanced cytosolic NADH content in SAMP8. We found that muscle of SAMP8, treated or not with NAC, evidenced significantly lower content in NADt, NADH and $\mathrm{NAD}^{+}$compounds compared to SAMR1 ( $\mathrm{p}<0.05$, Figure 7). However, $\mathrm{NADH} / \mathrm{NAD}^{+}$ratio was similar between all conditions (Figure 8).

Figure 8. In vivo muscle content in total NAD (NADt), reduced NAD (NADH), oxidized NAD (NAD+), and the ratio between NADH and NAD+, in SAMP8, SAMP8 receiving N-acetylcysteine (SAMP8-NAC) and SAMR1 ( $\mathrm{n}=10$ per group).

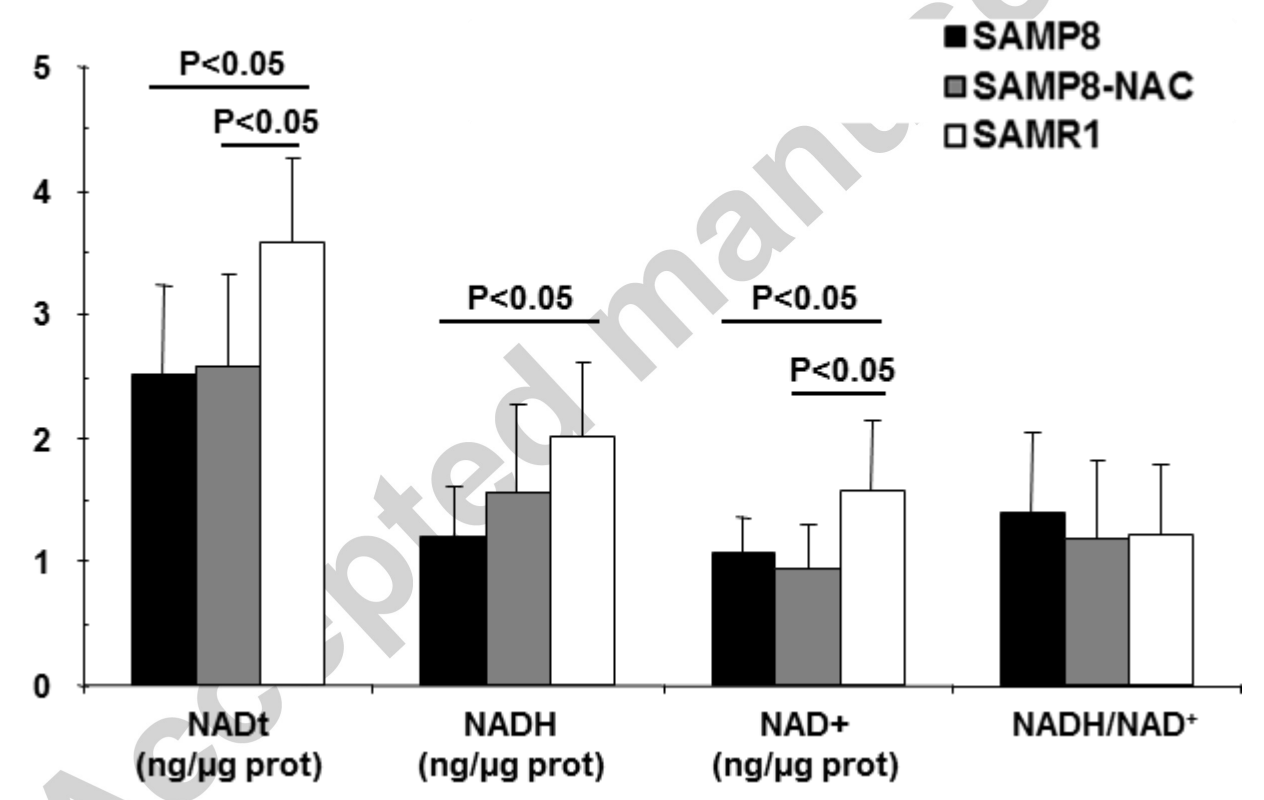

\section{Discussion}

Our study evidenced that SAMP8 are characterized by enhanced oxidative stress in skeletal muscle mainly due to high xanthine oxidase activity. High ROS production enhanced insulin signaling and glucose uptake but it also caused inhibition of mitochondrial complex I activity. These conflicting adaptations, with regards 
to the resulting imbalance between $\mathrm{NADH}$ production and use, were associated with adjustments in the mitochondrial respiration chain in SAMP8 compared to SAMR1: first, mitochondrial uncoupling, and second, enhanced complexes II and IV activity and associated respiration rates. Six months of NAC treatment reversed all SAMP8 characteristics to SAMR1 values, supporting that these adaptations were consecutive to high ROS production. We propose that in muscle of SAMP8, ROS impact on glucose metabolism and mitochondrial complex I activity is partially compensated by intrinsic adaptations of mitochondrial respiratory chain function, which may help at preserving metabolic flexibility.

It is the first time high xanthine oxidase expression is reported in skeletal muscle of SAMP8 mice. SAMP8 are used as a model of accelerated senescence and especially, of muscular aging (37). In agreement with this point, increased xanthine oxidase activity has been described with aging in skeletal muscle of other models (38-41). Yet in SAMP8 mice, the increased activity of xanthine oxidase is likely constitutive since the enzyme gene expression was 55-fold higher in skeletal muscle of SAMP8 compared to SAMR1 and this overexpression was not corrected by 6 months of NAC treatment. Corroborating the latter analysis, xanthine oxidase protein content was $30 \%$ higher in muscle of SAMP8 compared to SAMR1. Surprisingly, xanthine oxidase muscle content was corrected after 6 months of NAC treatment. Xanthine oxidase is an alternate form of the same gene product of xanthine dehydrogenase, which is the precursor. Xanthine dehydrogenase can be converted to xanthine oxidase by several processes, including hydrogen peroxide (42). Our present results thus suggest that the ratio between xanthine oxidase and xanthine dehydrogenase may differ by SAMP8 and SAMP8-NAC.

Exploration of the main intracellular sources of ROS production suggests that xanthine oxidase is the main cause of high ROS production in skeletal muscle of SAMP8 mice. Enhancing the antioxidant protection using NAC treatment helped at limiting the impact of high ROS production on muscle metabolism and restored insulin signaling, glucose uptake and mitochondrial functions of these animals to SAMR1 values. However, NAC treatment did not decrease xanthine oxidase activity; supporting our hypothesis that xanthine oxidase is constitutively enhanced in muscle of SAMP8 mice. 
In skeletal muscle of SAMP8, high ROS production was associated with adaptations in mitochondrial function but not content. Mitochondrial respiration rate with succinate/rotenone and Antimycine A/Ascorbate/TMPD/DNP were significantly higher in SAMP8 compared to SAMPR1, in agreement with higher maximal activity of complexes II and IV. Intriguingly with the substrates glutamate/malate, mitochondrial respiration rate was similar between the two strains despite a lower complex I catalytic activity in SAMP8, suggesting a balancing mechanism with the enhanced complex IV activity. In addition, in agreement with Echtay et al. (43) who demonstrated that ROS activate uncoupling proteins, our data show that part of the intrinsic adaptations of the mitochondrial respiration chain was due to enhanced mitochondrial uncoupling. Indeed, non-ADP stimulated state 4 respiration rate was 35, 59\% and 2-fold higher in SAMP8 compared to SAMR1 using substrates of complex I, complex II and glycerol-3-phosphate dehydrogenase shuttle, respectively. Contrasting with these observations, our data did not support the involvement of mitochondrial CoQ content in the adaptations of mitochondrial respiration of SAMP8 mice since CoQ9 and CoQ10 mitochondrial contents were similar between the two strains. We further failed to observe changes in the expression of major regulators of mitochondrial biogenesis (i.e. PGC-1alpha, PGC1beta, CREB, NRF-1, NRF-2, Tfam and PPARs) as well as that of key subunits of respiratory chain complexes. Therefore, our combined data suggest that mitochondrial adaptation in muscle of SAMP8 mainly relate to mitochondrial uncoupling, increased complexes II to IV activity and decreased intrinsic activity of complex I. Since all strain differences in mitochondrial function were corrected by 6 months of NAC treatment in SAMP8, our study supports that these mitochondrial adaptations are consecutive to high ROS production.

In agreement with previous reports which evidenced that ROS enhance glucose uptake (14), our present study showed that ex vivo muscle glucose uptake was $15 \%$ higher on average in SAMP8 compared to SAMR1, in the absence as well as in the presence of physiological and supra-physiological concentration of insulin. We thus hypothesized that the enhanced mitochondrial respiration capacity observed in muscle of SAMP8 may result from an adaptation for NADH metabolism caused by enhanced glycolysis and cytosolic NADH production. Our hypothesis was supported by a reduced basal glycemia, whereas insulinemia was similar, in SAMP8 compared to SAMR1, suggesting an enhanced glucose use in the P8 strain. The malate- 
aspartate and the glycerol-3-phosphate dehydrogenase shuttles are both involved in the transfer of reducing equivalents of cytosolic NADH into the mitochondria to power the complexes I and III, respectively. These two systems have been involved in several situations of metabolic adjustment to high fat diet (44) and resistance to obesity (45) in rodents, as well as to caloric restriction (46) and stress (47) in other models. However, both complex I and glycerol-3 Phosphate-related respiration rates were similar between SAMP8 and SAMR1. In addition, muscle content in NADH was significantly lower in SAMP8 compared to SAMR1, whereas NADH/NAD ${ }^{+}$ratio was similar. Finally, these strain differences were not altered by NAC treatment, although all other differences in mitochondrial functioning were. These combined results thus suggest that intrinsic adaptations of the mitochondrial respiratory chain do not result from adjustment to NADH metabolism but rather to ROS production.

Contrasting with the positive adaptations of the respiratory chain in SAMP8 compared to SAMR1, mitochondrial fatty acid oxidative capacity was similar between the two strains. In addition, mitochondrial fatty acid oxidative capacity was increased by $70 \%$ in SAMP8 treated with NAC. As proposed by Randle et al. (48), gene analyses suggest that PDK4 could be involved in this adaptation. Yet, the factors responsible for PDK4 enhanced expression remain to be identified. The involvement of PPARbeta is unclear since none of its known ligands were specifically enhanced in SAMP8-NAC compared to SAMP8, i.e. fatty acids (49), $\mathrm{H}_{2} \mathrm{O}_{2}$ (50), or even oxidized lipids (51) that may arise from the first two conditions. Nevertheless, these observations are important since they demonstrate that fatty acid oxidative capacity was maintained in SAMP8 despite high glycolytic activity, suggesting that mitochondrial adaptations to high ROS production may help at preserving metabolic flexibility. This hypothesis is supported by the fact that whole body RQ still adapts to nutritional transitions in SAMP8, with a tendency for a lower RQ during fasting periods and a higher RQ during periods of feeding and activity in comparison to SAMR1.

Interestingly, muscle insulin signaling varied as the mitochondrial function. In agreement with Loh et al. (16) who evidenced that ROS enhance insulin sensitivity, in vivo and in vitro muscle response to insulin was higher in SAMP8 compared to SAMR1. Furthermore, NAC treatment in SAMP8 restored the in vivo insulin response to SAMR1 values, supporting the involvement of ROS in this adaptation. This has been associated 
to ROS-mediated inhibition of phosphatases such as PTP1B, PTEN, PP2A and MAPKAP-1, resulting in an $\triangle C C E P T E D$ MANUSCRIPT

enhanced phosphorylation state of downwards targets of the insulin signaling pathway, such as Akt (13).

Adaptations in the insulin signaling pathway are independent from those observed in mitochondrial functions. Furthermore, mitochondrial function and insulin sensitivity are enhanced in SAMP8 mice compared to SAMR1, and both are decreased to SAMR1 values in NAC-treated SAMP8. Therefore, our study provides additional arguments that mitochondrial function and insulin signaling are closely, although indirectly, related.

Interestingly, we found that GLUT4 content was 32\% lower in muscle of SAMP8 compared to SAMR1 and that NAC treatment significantly increased this content to SAMR1 values. This is a surprising result which has not been reported before in skeletal muscle. Pessler D et al. (52) have demonstrated in the adipocyte lineage 3T3-L1 that oxidative stress causes decreased GLUT4 expression, associated with impaired binding of nuclear proteins to the insulin responsive element in the GLUT4 promoter. However in the present study, GLUT4 mRNA content was not significantly altered between strains. This suggests that the SAMP8 model may present specific adaptations in GLUT4 protein expression or proteolysis. Nevertheless, it is well known that GLUT4 total content in the tissue does not reflect the tissue response to insulin. Even if GLUT4 content is decreased in muscle of SAMP8, it is known that oxidative stress can stimulate GLUT4 translocation at the cell surface through a phosphatidylinositol 3-kinase-dependent pathway (53) thus contributing to the enhanced glucose uptake.

Finally, the higher glucose uptake in muscle of SAMP8 compare to SAMR1 is consistent with the in vivo results obtained in the fasted state but little with those obtained after insulin injection since in that situation, glycemia was $56 \%$ higher in SAMP8 compared to SAMR1 $(\mathrm{p}<0.01)$. We propose that the discrepancy may be explained by differences in insulin response between skeletal muscle and liver. On the one hand, the skeletal muscle takes up a high amount of glucose mainly because hydrogen peroxide acts as insulin mimetic whereas on the other hand, the liver may be insulin resistant due to another mechanism. This mechanism is however unknown since we did not explore liver metabolism and further studies are required to answer this question. 
In summary, SAMP8 are characterized by enhanced oxidative stress in skeletal muscle in comparison to SAMR1 due to high xanthine oxidase activity. High ROS production results in higher muscle insulin sensitivity, glucose uptake and mitochondrial oxidative activity, but subdued complex I activity, in SAMP8 compared to SAMR1. We propose that these ROS-driven adaptations help at preserving fatty acid oxidative capacity and metabolic flexibility which matches those of SAMR1 animals.

\section{Funding}

The work was supported by the authors' institution INRA, in particular through an ANSSD funding, and by a grant from the French Society of Diabetes (Société Francophone du Diabète, SFD).

\section{Acknowledgements}

The authors thank Chrystele Jouve, Christophe Montaurier, Véronique Patrac and Jean-Paul Rigaudière from the Human Nutrition Unit for their skillful technical assistance.

\section{Declaration of interest}

There is no conflict of interest to be declared. 


\section{References}

\section{ACCEPTED MANUSCRIPT}

1. DeFronzo RA, Gunnarsson R, Björkman O, Olsson M, Wahren J. Effects of insulin on peripheral and splanchnic glucose metabolism in noninsulin-dependent (type II) diabetes mellitus. J Clin Invest. 1985 Jul;76(1):149-55

2. Baron AD, Laakso M, Brechtel G, Edelman SV. Reduced capacity and affinity of skeletal muscle for insulin-mediated glucose uptake in noninsulin-dependent diabetic subjects. Effects of insulin therapy. J Clin Invest. 1991 Apr;87(4):1186-94

3. Bonnard C, Durand A, Peyrol S, Chanseaume E, Chauvin MA, Morio B, Vidal H, Rieusset J. Mitochondrial dysfunction results from oxidative stress in the skeletal muscle of diet-induced insulinresistant mice. J Clin Invest. 2008 Feb;118(2):789-800.

4. Bravard A, Bonnard C, Durand A, Chauvin MA, Favier R, Vidal H, Rieusset J. Inhibition of xanthine oxidase reduces hyperglycemia-induced oxidative stress and improves mitochondrial alterations in skeletal muscle of diabetic mice. Am J Physiol Endocrinol Metab. 2011 Mar;300(3):E581-91.

5. Bashan N, Kovsan J, Kachko I, Ovadia H, Rudich A. Positive and negative regulation of insulin signaling by reactive oxygen and nitrogen species. Physiol Rev. 2009 Jan;89(1):27-71

6. Aguirre V, Uchida T, Yenush L, Davis R, White MF. The c-Jun NH(2)-terminal kinase promotes insulin resistance during association with insulin receptor substrate-1 and phosphorylation of Ser(307). J Biol Chem. 2000 Mar 24;275(12):9047-54

7. Hirosumi J, Tuncman G, Chang L, Görgün CZ, Uysal KT, Maeda K, Karin M, Hotamisligil GS. A central role for JNK in obesity and insulin resistance. Nature. 2002 Nov 21;420(6913):333-6

8. Arkan MC, Hevener AL, Greten FR, Maeda S, Li ZW, Long JM, Wynshaw-Boris A, Poli G, Olefsky J, Karin M. IKK-beta links inflammation to obesity-induced insulin resistance. Nat Med. 2005 Feb;11(2):191-8

9. Barazzoni R, Zanetti M, Gortan Cappellari G, Semolic A, Boschelle M, Codarin E, Pirulli A, Cattin L, Guarnieri G. Fatty acids acutely enhance insulin-induced oxidative stress and cause insulin resistance by 
increasing mitochondrial reactive oxygen species (ROS) generation and nuclear factor- $\kappa \mathrm{B}$ inhibitor (I $\kappa \mathrm{B})$ nuclear factor- $\kappa \mathrm{B}(\mathrm{NF \kappa B})$ activation in rat muscle, in the absence of mitochondrial dysfunction. Diabetologia. 2012 Mar;55(3):773-82.

10. Houstis N, Rosen ED, Lander ES. Reactive oxygen species have a causal role in multiple forms of insulin resistance. Nature. 2006 Apr 13;440(7086):944-8.

11. Anderson EJ, Lustig ME, Boyle KE, Woodlief TL, Kane DA, Lin CT, Price JW 3rd, Kang L, Rabinovitch PS, Szeto HH, Houmard JA, Cortright RN, Wasserman DH, Neufer PD. Mitochondrial H2O2 emission and cellular redox state link excess fat intake to insulin resistance in both rodents and humans. J Clin Invest. 2009 Mar;119(3):573-81.

12. Hoehn KL, Salmon AB, Hohnen-Behrens C, Turner N, Hoy AJ, Maghzal GJ, Stocker R, Van Remmen H, Kraegen EW, Cooney GJ, Richardson AR, James DE. Insulin resistance is a cellular antioxidant defense mechanism. Proc Natl Acad Sci U S A. 2009 Oct 20;106(42):17787-92

13. Bashan N, Kovsan J, Kachko I, Ovadia H, Rudich A. Positive and negative regulation of insulin signaling by reactive oxygen and nitrogen species. Physiol Rev. 2009 Jan;89(1):27-71.

14. Higaki Y, Mikami T, Fujii N, Hirshman MF, Koyama K, Seino T, Tanaka K, Goodyear LJ. Oxidative stress stimulates skeletal muscle glucose uptake through a phosphatidylinositol 3-kinasedependent pathway. Am J Physiol Endocrinol Metab. 2008 May;294(5):E889-97

15. Jensen TE, Schjerling P, Viollet B, Wojtaszewski JF, Richter EA. AMPK alpha1 activation is required for stimulation of glucose uptake by twitch contraction, but not by $\mathrm{H} 2 \mathrm{O} 2$, in mouse skeletal muscle. PLoS One. 2008 May 7;3(5):e2102.

16. Loh K, Deng H, Fukushima A, Cai X, Boivin B, Galic S, Bruce C, Shields BJ, Skiba B, Ooms LM, Stepto N, Wu B, Mitchell CA, Tonks NK, Watt MJ, Febbraio MA, Crack PJ, Andrikopoulos S, Tiganis T. Reactive oxygen species enhance insulin sensitivity. Cell Metab. 2009 Oct;10(4):260-72.

17. Yokota T, Kinugawa S, Hirabayashi K, Matsushima S, Inoue N, Ohta Y, Hamaguchi S, Sobirin MA, Ono T, Suga T, Kuroda S, Tanaka S, Terasaki F, Okita K, Tsutsui H. Oxidative stress in skeletal muscle 
impairs mitochondrial respiration and limits exercise capacity in type 2 diabetic mice. Am J Physiol Heart Circ Physiol. 2009 Sep;297(3):H1069-77

18. Montgomery MK, Turner N. Mitochondrial dysfunction and insulin resistance: anupdate. Endocr Connect. 2015 Mar;4(1):R1-R15

19. Rebrin I, Sohal RS. Comparison of thiol redox state of mitochondria and homogenates of various tissues between two strains of mice with different longevities. Exp Gerontol. 2004 Oct;39(10):1513-9

20. Liu HW, Chan YC, Wang MF, Wei CC, Chang SJ. Dietary (-)-Epigallocatechin-3-gallate Supplementation Counteracts Aging-Associated Skeletal Muscle Insulin Resistance and Fatty Liver in Senescence-Accelerated Mouse. J Agric Food Chem. 2015 Sep 30;63(38):8407-17.

21. Kishida Y, Kagawa S, Arimitsu J, Nakanishi M, Sakashita N, Otsuka S, Yoshikawa H, Hagihara K. Go-sha-jinki-Gan (GJG), a traditional Japanese herbal medicine, protects against sarcopenia in senescenceaccelerated mice. Phytomedicine. 2015 Jan 15;22(1):16-22.

22. Kurokawa T, Ozaki N, Ishibashi S. Difference between senescence-accelerated prone and resistant mice in response to insulin in the heart. Mech Ageing Dev. 1998 May 1;102(1):25-32.

23. Liu HW, Chan YC, Wang MF, Wei CC, Chang SJ. Dietary (-)-Epigallocatechin-3-gallate Supplementation Counteracts Aging-Associated Skeletal Muscle Insulin Resistance and Fatty Liver in Senescence-Accelerated Mouse. J Agric Food Chem. 2015 Sep 30;63(38):8407-17.

24. Rodríguez MI, Escames G, López LC, López A, García JA, Ortiz F, Sánchez V, Romeu M, AcuñaCastroviejo D. Improved mitochondrial function and increased life span after chronic melatonin treatment in senescent prone mice. Exp Gerontol. 2008 Aug;43(8):749-56.

25. Zimmermann, 1993: Guidelines for Animal Research by the International Association for the Study of Pain

26. Brower et al.,

27. Flohe, L.; Gunzler, W. A. Assays of glutathione peroxidase. Methods Enzymol. 105:114-121; 1984. 
28. Beers, R.; Sizer, I. A spectrophotometric method for measuring the breakdown ofhydrogen peroxide by catalase. J. Biol. Chem. 195:133-140; 1952.

29. Marklund, S. Spectrophotometric study of spontaneous disproportionation of superoxide anion radical and sensitiv

30. Griffith, O. W. Determination of glutathione and glutathione disulfide using glutathione reductase and 2-vinylpyridine. Anal Biochem 106:207-212; 1980

31. Galinier A, Carrière A, Fernandez Y, Bessac AM, Caspar-Bauguil S, Periquet B, Comtat M, Thouvenot JP, Casteilla L. Biological validation of coenzyme Q redox state by HPLC-EC measurement: relationship between coenzyme Q redox state and coenzyme Q content in rat tissues. FEBS Lett. 2004 Dec 3;578(1-2):53-7.

32. Capel F, Rimbert V, Lioger D, Diot A, Rousset P, Mirand PP, Boirie Y, Morio B, Mosoni L. Due to reverse electron transfer, mitochondrial $\mathrm{H} 2 \mathrm{O} 2$ release increaseswith age in human vastus lateralis muscle although oxidative capacity is preserved. Mech Ageing Dev. 2005 Apr;126(4):505-11.

33. Batandier C, Fontaine E, Kériel C, Leverve XM. Determination of mitochondrial reactive oxygen species: methodological aspects. J Cell Mol Med. 2002 Apr-Jun;6(2):175-87.

34. Morio, B., J. F. Hocquette, C. Montaurier, Y. Boirie, C. Bouteloup-Demange, C. McCormack, N. Fellmann, B. Beaufrere and P. Ritz. 2001. Muscle fatty acid oxidative capacity is a determinant of whole body fat oxidation in elderly people. Am J Physiol Endocrinol Metab. 280: E143-149.

35. Nahlé Z, Hsieh M, Pietka T, Coburn CT, Grimaldi PA, Zhang MQ, Das D, Abumrad NA. CD36dependent regulation of muscle FoxO1 and PDK4 in the PPAR delta/beta-mediated adaptation to metabolic stress. J Biol Chem. 2008 May 23;283(21):14317-26.

36. Nishino T \& Tamura I. Purine and Pyrimidine Metabolism in Man VII pp 327-333

37. Romanick M, Thompson LV, Brown-Borg HM. Murine models of atrophy, cachexia,and sarcopenia in skeletal muscle. Biochim Biophys Acta. 2013 Sep;1832(9):1410-20. 
38. Tarry-Adkins JL, Fernandez-Twinn DS, Chen JH, Hargreaves IP, Neergheen V, Aiken CE, Ozanne ACCEPTED MANUSCRIPT

SE. Poor maternal nutrition and accelerated postnatal growth induces an accelerated aging phenotype and oxidative stress in skeletal muscle of male rats. Dis Model Mech. 2016 Oct 1;9(10):1221-1229.

39. Ryan MJ, Jackson JR, Hao Y, Leonard SS, Alway SE. Inhibition of xanthine oxidase reduces oxidative stress and improves skeletal muscle function in response to electrically stimulated isometric contractions in aged mice. Free Radic Biol Med. 2011 Jul 1;51(1):38-52.

40. Huang CC, Tsai SC, Lin WT. Potential ergogenic effects of L-arginine against oxidative and inflammatory stress induced by acute exercise in aging rats. Exp Gerontol. 2008 Jun;43(6):571-7.

41. Hofer T, Marzetti E, Xu J, Seo AY, Gulec S, Knutson MD, Leeuwenburgh C, upont-Versteegden EE. Increased iron content and RNA oxidative damage in skeletal muscle with aging and disuse atrophy. Exp Gerontol. 2008 Jun;43(6):563-70.

42. McNally JS, Saxena A, Cai H, Dikalov S, Harrison DG. Regulation of xanthine oxidoreductase protein expression by hydrogen peroxide and calcium. Arterioscler Thromb Vasc Biol. 2005;25:1623-8.

43. Echtay KS, Roussel D, St-Pierre J, Jekabsons MB, Cadenas S, Stuart JA, Harper JA, Roebuck SJ, Morrison A, Pickering S, Clapham JC, Brand MD. Superoxide activates mitochondrial uncoupling proteins. Nature. 2002 Jan 3;415(6867):96-9.

44. Iossa S, Mollica MP, Lionetti L, Barletta A, Liverini G. Hepatic mitochondrial respiration and transport of reducing equivalents in rats fed an energy dense diet. Int J Obes Relat Metab Disord. 1995 Aug;19(8):539-43.

45. Taleux N, Guigas B, Dubouchaud H, Moreno M, Weitzel JM, Goglia F, Favier R, Leverve XM. High expression of thyroid hormone receptors and mitochondrial glycerol-3-phosphate dehydrogenase in the liver is linked to enhanced fatty acidoxidation in Lou/C, a rat strain resistant to obesity. J Biol Chem. 2009 Feb 13;284(7):4308-16. 
46. Easlon E, Tsang F, Skinner C, Wang C, Lin SJ. The malate-aspartate NADH shuttle components are ACCEPTED MANUSCR/PT

novel metabolic longevity regulators required for calorie restriction-mediated life span extension in yeast. Genes Dev. 2008 Apr 1;22(7):931-44.

47. Shen W, Wei Y, Dauk M, Tan Y, Taylor DC, Selvaraj G, Zou J. Involvement of a glycerol-3phosphate dehydrogenase in modulating the NADH/NAD+ ratio provides evidence of a mitochondrial glycerol-3-phosphate shuttle in Arabidopsis. Plant Cell. 2006 Feb;18(2):422-41.

48. Randle PJ, Priestman DA, Mistry S, Halsall A. Mechanisms modifying glucose oxidation in diabetes mellitus. Diabetologia. 1994 Sep;37 Suppl 2:S155-61.

49. Nahlé Z, Hsieh M, Pietka T, Coburn CT, Grimaldi PA, Zhang MQ, Das D, Abumrad NA. CD36dependent regulation of muscle FoxO1 and PDK4 in the PPAR delta/beta-mediated adaptation to metabolic stress. J Biol Chem. 2008 May 23;283(21):14317-26.

50. Jiang B, Liang P, Zhang B, Huang X, Xiao X. Enhancement of PPAR-beta activity by repetitive lowgrade $\mathrm{H}(2) \mathrm{O}(2)$ stress protects human umbilical vein endothelial cells from subsequent oxidative stressinduced apoptosis. Free Radic Biol Med. 2009 Mar 1;46(5):555-63.

51. Coleman JD, Prabhu KS, Thompson JT, Reddy PS, Peters JM, Peterson BR, Reddy CC, Vanden Heuvel JP. The oxidative stress mediator 4-hydroxynonenal is an intracellular agonist of the nuclear receptor peroxisome proliferator-activated receptor-beta/delta (PPARbeta/delta). Free Radic Biol Med. 2007 Apr 15;42(8):1155-64.

52. Pessler D, Rudich A, Bashan N. Oxidative stress impairs nuclear proteins binding to the insulin responsive element in the GLUT4 promoter. Diabetologia. 2001;44:2156-64.

53. Higaki Y, Mikami T, Fujii N, Hirshman MF, Koyama K, Seino T, Tanaka K, Goodyear LJ. Oxidative stress stimulates skeletal muscle glucose uptake through a phosphatidylinositol 3-kinasedependent pathway. Am J Physiol Endocrinol Metab. 2008;294:E889-97. 


\section{Highlights}

- Xanthine oxidase ROS production is higher in muscle of SAMP8 vs. SAMR1

- High ROS production is linked to higher insulin sensitivity and glucose uptake

- High ROS production causes lower mitochondrial complex I activity

- High ROS production causes intrinsic adjustments in the mitochondrial respiration chain

- These bioenergetics adaptations may help at preserving muscle metabolic flexibility 